\title{
Modified 1913 Reference Tables for Iron-Constantan Thermocouples
}

\author{
Robert J. Corruccini and Henry Shenker
}

\begin{abstract}
An investigation was made of the characteristics of iron-constantan thermocouples typical of those being supplied to reproduce the standard temperature-electromotive force relationship that was established commercially in 1913. Using the calibration of the thermocouple that most nearly matched the 1913 reference table over the range to which ironconstantan thermocouples usually are limited $\left(32^{\circ}\right.$ to $\left.1,400^{\circ} \mathrm{F}\right)$, a slightly different temperature-electromotive force relationship was derived which is more nearly realizable by commercially available materials. The new relationship is presented in four mutually consistent tables covering the range, $-320^{\circ}$ to $+1,600^{\circ} \mathrm{F}\left(-196^{\circ}\right.$ to $\left.+871^{\circ} \mathrm{C}\right)$, in both Fahrenheit and Celsius units and with both temperature and electromotive force as arguments.
\end{abstract}

\section{Introduction}

The application of thermocouples to pyrometry has been accompanied by the development of indicating instruments (millivoltmeters, potentiometers) with scales calibrated so as to indicate temperature directly. Such scale calibration requires a knowledge of the temperature-emf relationship of the associated thermocouple. In general, the thermocouple is required to be readily replaceable, whereas the associated indicator is relatively long-lived. It is not practical to alter the scale of the indicator to allow for changes in the characteristics of the thermocouples used with it. Consequently, each manufacturer of a given type of thermoelectric pyrometer calibrates the scales of the indicator in accordance with a definite temperature-emf relationship (reference table) and undertakes to furnish replacement thermocouples that satisfy this relationship within certain narrow limits.

Several reference tables have existed in the past for each of the common thermocouples, each supplier adopting, for a given type of thermocouple, a table (or sometimes two) that was thought to represent closely the thermocouples supplied by that company. Thus, a partial survey in 1937 showed the existence of four reference tables for iron-constantan thermocouples, differing from each other by as much as 7 percent.

In the years 1933 to 1938 , the National Bureau of Standards published reference tables for all of the common thermocouples $[1,2,3] .^{1,2}$ These tables were based on laboratory calibrations of numerous representative samples of these thermocouples. The tables in RP530 for platinum-platinum rhodium and those in RP1080 for copper-constantan were based on older tables and soon were widely accepted. The tables for chromel-alumel in RP767 likewise were widely accepted. Here, the situation was simplified by the fact that all chromel-P and alumel originates with one producer who prepares these alloys to a single set of specifications.

${ }^{1}$ Figures in brackets indicate the literature references at the end of this paper. 2 Most of the same tables are now available in expanded and revised form in NBS Circular 508, Reference Tables for Thermocouples, by Henry Shenker, John I. Lauritzen, Jr., and Robert J. Corruccini, issued May 7, 1951.
On the other hand, the tables for iron-constantan thermocouples published in RP1080 were the result of an investigation that began after another Government agency had noted that the NBS calibrations of iron-constantan thermocouples being purchased in the early 1930 's did not match closely any existing reference table. The reference table in $\mathrm{RP} 1080$ represented an average of the commercially available thermocouples tested at that time and, hence, did not resemble closely any of the older tables for this type of thermocouple. RP1080 showed the manufacturers the necessity of either (1) altering the scales of new indicators, and of some existing ones, to conform to a temperature-emf relationship that was representative of the thermocouples actually being produced (RP1080), or (2) to develop new thermocouple materials that would have, within the desired tolerances, the temperature-emf relationship embodied in the scales of the existing indicators. Most of the manufacturers chose the latter course. Users with large investments in installed indicators were satisfied with this development, and the RP1080 table has not displaced the previous tables to any great extent, although it is the only table used for iron-constantan thermocouples in the field of military aircraft.

A further difference between the situations for iron-constantan and the other common thermocouples is related to the manner of procurement. Thermoelectric platinum and platinum-rhodium are prepared to specifications having the end use in view. Constantan and the purer grades of copper likewise are prepared with careful attention to the electrical properties of the product. On the other hand, such a small proportion of the total production of iron goes to thermocouples, that large producers of iron cannot be interested in controlling the properties of their product so as to suit it to this use. The manufacturer of pyrometers thus finds it more economical to select from the available production of commercial iron certain lots that happen to be suitable for thermoelectric use, rather than to have a suitable material prepared to specifications at a premium price by a producer of specialty metals. In classifying lots of iron, chemical tests are helpful, but the 
final test of the suitability of a lot must be a thermoelectric one.

In an effort to promote uniformity, steps were initiated in 1948 in the Recorder-Controller Section of the Scientific Apparatus Makers of America (SAMA), representing a number of pyrometer manufacturers, directed toward the adoption of the temperature-emf relationship known as the "1913" table ${ }^{3}$ as a tentative standard for iron-constantan thermocouples over the range, $32^{\circ}$ to $1,400^{\circ} \mathrm{F}$. This table was chosen because it is used more than any other. It is apparently based on a single calibration of a thermocouple (no longer in existence) that was typical of the iron-constantan of forty years ago. However, experience has shown that it is apparently not possible to produce a thermocouple, using presentday commercial iron, that will correspond precisely to the 1913 table. In addition, it was desired that the standard table should extend to subzero temperatures, whereas the original 1913 table did not extend below $32^{\circ} \mathrm{F}$.

It appeared that experimental data on the characteristics of thermocouples of the type that reproduce the 1913 table were required in order to (1) judge the adequacy of the 1913 table as a permanent standard for SAMA, or, if it should prove desirable,

\footnotetext{
3 'This table, sometimes called the Leeds and Northrup table, is identical with the tables given in International Critical Tables, 1, 59, (1926) and in Tech. Pap. BS 14, 306 (1920-21) T170, Table IV, Col. L.
}

to make adjustments in the table, and (2) to obtain data at low temperatures. Accordingly, a research project for this purpose was established at the NBS and was supported in part by a grant from SAMA and in part by funds of the Bureau. This paper presents the results of this investigation.

\section{Experimental Procedure}

Each member firm of the SAMA that supplies iron-constantan thermocouples was invited to submit samples for investigation at the Bureau. These thermocouples were to be of commercial materials that were selected to match closely the 1913 table over the range $32^{\circ}$ to $1,400^{\circ} \mathrm{F}$. Of the 8 eligible member concerns, 4 responded. Of these, 3 furnished 1 lot of wire each, while the fourth concern furnished 5 different lots of wire. The samples were designated by a letter representing the supplier, followed by a number representing the sample, e. g. $\mathrm{A}-1$. The wire size was approximately No. $8 \mathrm{AWG}$. Information received from some of the suppliers indicated that the iron samples came from at least four different basic sources of ingot iron.

The thermoelectric measurements were made in two parts: (a) From $32^{\circ}$ to $1,800^{\circ} \mathrm{F}$ the wires were calibrated in a tube-furnace which has already been described [4,5]. For convenience, the iron wires

TABLE 1. Corresponding values of temperature and electromotive force for iron wires versus $\mathrm{Pt}-27$

(Reference junctions at $32^{\circ} \mathrm{F}$ )

\begin{tabular}{|c|c|c|c|c|c|c|c|c|}
\hline \multirow{2}{*}{$\begin{array}{l}\text { Tempera- } \\
\text { ture (Int. } \\
1948 \text { ) }\end{array}$} & \multicolumn{8}{|c|}{ Thermal electromotive force (absolute millivolts) for samples- } \\
\hline & $\mathrm{A}-1$ & $\mathrm{C}-1$ & $\mathrm{D}-1$ & $\mathrm{~F}-1$ & $\mathrm{~F}-3$ & $\mathrm{~F}-4$ & $\mathrm{~F}-5$ & $\mathrm{~F}-6$ \\
\hline${ }^{\circ} \mathrm{F}$ & & & & & & & & \\
\hline-319.5 & -2.54 & -2.64 & -2.54 & -2.65 & -2.22 & -2.43 & -2.35 & -2.29 \\
\hline-297.4 & -2.50 & -2.60 & -2.50 & -2.60 & -2.19 & -2.40 & -2.32 & -2.26 \\
\hline-147.1 & -1.65 & -1.72 & -1.66 & -1.70 & -1.49 & -1.61 & -1.56 & -1.52 \\
\hline-103.0 & -1.28 & -1.33 & -1.28 & -1.31 & -1.17 & -1.25 & -1.21 & -1.18 \\
\hline-61.8 & -0.91 & -0.95 & -0.91 & -0.93 & -0.83 & -0.89 & -0.86 & -0.84 \\
\hline-27.6 & -0.58 & -0.61 & -0.59 & -0.59 & -0.54 & -0.58 & -0.55 & -0.54 \\
\hline+32 & 0.00 & 0.00 & 0.00 & 0. 00 & 0.00 & 0. 00 & 0. 00 & 0. 00 \\
\hline 100 & +0.68 & +0.71 & $\begin{array}{r}0.68 \\
\end{array}$ & +0.68 & +0.64 & +0.67 & +0.65 & +0.64 \\
\hline 200 & 1. 66 & 1. 74 & 1. 67 & 1. 66 & 1. 59 & 1. 65 & 1. 60 & 1. 57 \\
\hline 300 & 2. 59 & 2. 72 & 2. 60 & 2. 56 & 2.50 & 2. 57 & 2. 50 & 2. 46 \\
\hline 400 & 3. 44 & 3. 62 & 3. 46 & 3. 38 & 3.35 & 3. 42 & 3. 32 & 3. 27 \\
\hline 500 & 4. 20 & 4. 42 & 4. 23 & 4. 09 & 4. 13 & 4. 18 & 4. 06 & 4. 00 \\
\hline 600 & 4. 86 & 5. 13 & 4. 90 & 4. 70 & 4. 82 & 4. 84 & 4. 70 & 4. 64 \\
\hline 700 & 5. 45 & 5. 76 & 5. 49 & 5. 25 & 5. 45 & 5. 43 & 5. 28 & 5. 21 \\
\hline 800 & 5. 99 & 6.34 & 6. 04 & 5. 74 & 6. 03 & 5. 97 & 5. 81 & 5. 73 \\
\hline 900 & 6. 52 & 6. 90 & 6.57 & 6. 23 & 6. 60 & 6. 49 & 6. 32 & 6. 24 \\
\hline 1,000 & 7. 06 & 7. 47 & 7. 12 & 6. 74 & 7. 17 & 7. 03 & 6. 86 & 6. 77 \\
\hline 1,100 & 7. 66 & 8. 09 & 7. 72 & 7. 31 & 7. 80 & 7. 63 & 7. 45 & 7. 36 \\
\hline 1,200 & 8. 34 & 8. 79 & 8. 41 & 7. 97 & 8.51 & 8. 31 & 8. 12 & 8. 04 \\
\hline 1,300 & 9. 14 & 9. 60 & 9. 21 & 8. 76 & 9. 33 & 9. 11 & 8. 92 & 8. 83 \\
\hline 1,400 & 10. 07 & 10.52 & 10. 15 & 9. 68 & 10. 25 & 10. 04 & 9. 84 & 9. 76 \\
\hline 1,500 & 11. 06 & 11. 44 & 11. 17 & 10. 73 & 11. 21 & 11. 08 & 10. 85 & 10. 76 \\
\hline 1,600 & 12. 01 & 12. 26 & 12. 19 & 11. 83 & 12. 11 & 12. 19 & 11. 86 & 11. 71 \\
\hline 1,700 & 12. 77 & 12. 98 & 12. 94 & 12. 76 & 12. 89 & 13. 20 & 12. 70 & 12. 61 \\
\hline 1,800 & 13.57 & 13. 79 & 13. 75 & 13. 61 & 13. 71 & 14. 00 & 13.51 & 13. 44 \\
\hline
\end{tabular}


were calibrated against a standard iron wire, and the constantan wires against a standard constantan wire. The standard iron and the standard constantan wires had previously been calibrated against Pt 27, the platinum thermoelectric standard of the NBS, and they were rechecked at frequent intervals during each run against the platinum element of the platinum versus platinum-10 percent rhodium thermocouple used to measure the temperature. The test wires were calibrated three at a time. The measuring junctions of the test wires, the standard wire of the same material, and the platinum versus platinum-rhodium thermocouple used to measure the temperature were welded together. Because of the relative instability of the iron and constantan at temperatures above $1,400^{\circ} \mathrm{F}$, measurements in this range were made against a platinum standard only. The average rate of rise of temperature in the region. above $1,400^{\circ} \mathrm{F}$ was about $8 \mathrm{deg} \mathrm{F}$ per minute. All measurements were made at $100 \mathrm{deg} \mathrm{F}$ intervals on rising temperature. After each run, the heated section of the iron or constantan standard was cut off and discarded. The methods used were similar to those described in $[4$, p. 262-5, 277]. The measurements are considered to be accurate within the equivalent of $1 \mathrm{deg} \mathrm{F}$. (b) From $+32^{\circ}$ to $-319.5^{\circ}$ $\mathrm{F}$, the thermal emf of each wire against a copper reference wire was determined in stirred liquid baths. The copper reference wires were calibrated against a platinum standard. Down to $-147^{\circ} \mathrm{F}$ the cryostat described by Scott $[6 ; 5$, p. 206] was used. Observations at two lower temperatures were made by using baths of liquid oxygen and nitrogen stirred by a stream of the same gas. Temperatures in the baths were determined with a platinum resistance thermometer. Sections of wire that had not been previously heated were used for the low-temperature measurements. The limit of error in this range is considered to be the equivalent of $1 / 2 \mathrm{deg} \mathrm{F}$.

In all the measurements, the reference junctions were kept at $32^{\circ} \mathrm{F}$ in a mixture of ice and water. An atmosphere of air surrounded the thermocouples at all times. The calibrations of the individual wires relative to $\mathrm{Pt} 27$ at the various calibration temperatures were compiled and are given in tables 1 and 2 . The data in table 3 for the complete thermocouples were obtained by combination of the data in tables 1 and 2 .

The deviations (expressed in $\mathrm{deg} \mathrm{F}$ ) of the various thermocouples from the 1913 table are shown in figure 1. The deviation of the RP1080 table is also shown. Because the $\mathrm{A}-1$ thermocouple gave the nearest over-all match to the 1913 table in the range up to $1,400^{\circ} \mathrm{F}$, the calibrations of the iron and constantan elements of this thermocouple were used as base lines for figures 2 and 3 , respectively, in which are shown the differences among the various individual wires. The curves marked "RP1080" repre-

TABLE 2. Corresponding values of temperature and electromotive forces for constantan wires versus $\mathrm{Pt}-27$

(Reference junctions at $32^{\circ} \mathrm{F}$ )

\begin{tabular}{|c|c|c|c|c|c|c|c|}
\hline \multirow{2}{*}{$\begin{array}{c}\text { Tempera- } \\
\text { ture (Int. } \\
1948)\end{array}$} & \multicolumn{7}{|c|}{ Thermal electromotive force (absolute millivolts) for samples- } \\
\hline & $A-1$ & $\mathrm{C}-1$ & D-1 & $\mathrm{F}-1, \mathrm{~F}-6$ & $\mathrm{~F}-3$ & $\mathrm{~F}-4$ & $\mathrm{~F}-5$ \\
\hline${ }^{\circ} \mathrm{F}$ & & & & & & & \\
\hline-319.5 & +5.24 & +5.14 & +5.24 & +5.31 & +5.24 & +5.30 & +5.30 \\
\hline-297.4 & 4. 99 & 4. 89 & 4. 99 & 5. 05 & 4. 98 & 5. 04 & 5. 04 \\
\hline-147.1 & 2. 96 & 2. 90 & 2. 95 & 2. 99 & 2. 95 & 2. 99 & 2. 99 \\
\hline-103.0 & 2. 28 & 2. 33 & 2. 28 & 2. 31 & 2. 28 & 2. 31 & 2. 31 \\
\hline-61.8 & 1. 62 & 1. 59 & 1. 62 & 1. 64 & 1. 62 & 1. 64 & 1. 64 \\
\hline-27.6 & 1. 05 & 1. 03 & 1. 05 & 1. 06 & 1. 05 & 1. 06 & 1. 06 \\
\hline+32 & 0.00 & 0.00 & 0.00 & 0.00 & 0.00 & 0.00 & 0.00 \\
\hline 100 & -1.26 & -1.24 & -1.27 & -1.28 & -1.26 & -1.28 & -1.28 \\
\hline 200 & -3.24 & -3.17 & -3.25 & -3.29 & -3.24 & -3.28 & -3.28 \\
\hline 300 & -5.35 & -5.26 & -5.34 & -5.43 & -5.35 & -5.42 & -5.42 \\
\hline 400 & -7.58 & -7.46 & -7.60 & -7.69 & -7.58 & -7.67 & -7.67 \\
\hline 500 & -9.92 & -9.75 & -9.93 & -10.04 & -9.90 & -10.01 & -10.02 \\
\hline 600 & -12.32 & -12.10 & -12.33 & -12.47 & -12.30 & -12.43 & -12.45 \\
\hline 700 & -14.80 & -14.54 & -14.80 & -14.97 & -14.76 & -14.92 & -14.95 \\
\hline 800 & -17.33 & -17.01 & -17.31 & -17.51 & -17.25 & -17.45 & -17.48 \\
\hline 900 & -19.88 & -19.51 & -19.85 & -20.08 & -19.78 & -20.01 & -20.05 \\
\hline 1,000 & -22.46 & -22.06 & -22.42 & -22.68 & -22.34 & -22.60 & -22.64 \\
\hline 1,100 & -25.07 & -24.61 & -25.00 & -25.29 & -24.91 & -25.20 & -25.25 \\
\hline 1,200 & -27.67 & -27.18 & -27.59 & -27.90 & -27.49 & -27.80 & -27.86 \\
\hline 1,300 & -30.29 & -29.76 & -30.18 & -30.52 & -30.07 & -30.41 & -30.48 \\
\hline 1,400 & -32.89 & -32.32 & -32.77 & -33.13 & -32.64 & -33.01 & -33.08 \\
\hline 1,500 & -35.48 & -34.86 & -35.32 & -35.71 & -35.16 & -35.59 & -35.66 \\
\hline 1,600 & -38.04 & -37.28 & -37.86 & -38.27 & -37.72 & -38.15 & -38.22 \\
\hline 1,700 & -40.57 & -39.87 & -40.36 & -40.79 & -40.22 & -40.67 & -40.74 \\
\hline 1,800 & -43.06 & -42.34 & -42.84 & -43.29 & -42.68 & -43.15 & -43.23 \\
\hline
\end{tabular}


TABLE 3. Corresponding values of temperature and electromotive force for iron-constantan thermocouples

(Reference junctions at $32^{\circ} \mathrm{F}$ )

\begin{tabular}{|c|c|c|c|c|c|c|c|c|c|c|}
\hline \multirow{2}{*}{$\begin{array}{c}\text { Temper- } \\
\text { ature } \\
\text { (Int. 1948) }\end{array}$} & \multicolumn{10}{|c|}{ Thermal electromotive force (absolute millivolts) for samples- } \\
\hline & $\mathrm{A}-1$ & $\mathrm{C}-1$ & D-1 & $\mathrm{F}-1$ & $\mathrm{~F}-3$ & $\mathrm{~F}-4$ & $\mathrm{~F}-5$ & $\mathrm{~F}-6$ & $\begin{array}{c}1913 \\
\text { table }\end{array}$ & $\begin{array}{c}\text { RP1080 } \\
\text { table }\end{array}$ \\
\hline $\begin{array}{r}{ }^{\circ} F \\
-319.5 \\
-297.4 \\
-147.1 \\
-103.0 \\
-61.8\end{array}$ & $\begin{array}{l}-7.79 \\
-7.49 \\
-4.61 \\
-3.56 \\
-2.53\end{array}$ & $\begin{array}{l}-7.79 \\
-7.49 \\
-4.62 \\
-3.57 \\
-2.53\end{array}$ & $\begin{array}{r}-7.78 \\
-7.49 \\
-4.61 \\
-3.56 \\
-2.53\end{array}$ & $\begin{array}{l}-7.96 \\
-7.65 \\
-4.69 \\
-3.62 \\
-2.57\end{array}$ & $\begin{array}{l}-7.45 \\
-7.17 \\
-4.44 \\
-3.44 \\
-2.45\end{array}$ & $\begin{array}{l}-7.73 \\
-7.44 \\
-4.59 \\
-3.55 \\
-2.53\end{array}$ & $\begin{array}{l}-7.66 \\
-7.37 \\
-4.55 \\
-3.52 \\
-2.50\end{array}$ & $\begin{array}{r}-7.60 \\
-7.31 \\
-4.51 \\
-3.49 \\
-2.48\end{array}$ & $\begin{array}{l}-\cdots \\
-\cdots \\
-\cdots- \\
-\cdots-\end{array}$ & $\begin{array}{l}-7.83 \\
-4.80 \\
-3.71 \\
-2.63\end{array}$ \\
\hline $\begin{array}{l}-27.6 \\
+32 \\
100 \\
200 \\
300\end{array}$ & $\begin{array}{r}-1.63 \\
0.00 \\
+1.94 \\
4.91 \\
7.94\end{array}$ & $\begin{array}{r}-1.63 \\
0.00 \\
+1.94 \\
4.91 \\
7.97\end{array}$ & $\begin{array}{r}-1.63 \\
0.00 \\
+1.95 \\
4.92 \\
7.97\end{array}$ & $\begin{array}{r}-1.65 \\
0.00 \\
+1.96 \\
4.95 \\
7.99\end{array}$ & $\begin{array}{r}-1.58 \\
0.00 \\
+1.90 \\
4.83 \\
7.85\end{array}$ & $\begin{array}{r}-1.63 \\
0.00 \\
+1.95 \\
4.93 \\
7.99\end{array}$ & $\begin{array}{r}\text { 1. } 61 \\
0.00 \\
+ \text { 1. } 93 \\
\text { 4. } 88 \\
\text { 7. } 91\end{array}$ & $\begin{array}{r}-1.60 \\
0.00 \\
+1.92 \\
\text { 4. } 86 \\
7.88\end{array}$ & $\begin{array}{r}0.00 \\
+1.96 \\
\text { 4. } 92 \\
\text { 7. } 95\end{array}$ & $\begin{array}{r}-1.69 \\
0.00 \\
+2.00 \\
5.03 \\
8.13\end{array}$ \\
\hline $\begin{array}{l}400 \\
500 \\
600 \\
700 \\
800\end{array}$ & $\begin{array}{l}11.03 \\
14.12 \\
17.18 \\
20.26 \\
23.32\end{array}$ & $\begin{array}{l}\text { 11. } 07 \\
14.17 \\
\text { 17. } 23 \\
\text { 20. } 30 \\
23.35\end{array}$ & $\begin{array}{l}11.07 \\
14.16 \\
\text { 17. } 23 \\
20.30 \\
23.35\end{array}$ & $\begin{array}{l}\text { 11. } 06 \\
14.13 \\
\text { 17. } 17 \\
\text { 20. } 22 \\
23.25\end{array}$ & $\begin{array}{l}\text { 10. } 93 \\
14.03 \\
\text { 17. } 12 \\
20.21 \\
23.29\end{array}$ & $\begin{array}{l}\text { 11. } 09 \\
14.19 \\
\text { 17. } 27 \\
\text { 20. } 35 \\
\text { 23. } 42\end{array}$ & $\begin{array}{l}11.00 \\
14.08 \\
17.15 \\
20.23 \\
23.29\end{array}$ & $\begin{array}{l}\text { 10. } 96 \\
14.04 \\
\text { 17. } 10 \\
\text { 20. } 18 \\
23.24\end{array}$ & $\begin{array}{l}\text { 11. } 02 \\
14.10 \\
17.17 \\
20.24 \\
23.32\end{array}$ & $\begin{array}{l}11.25 \\
14.35 \\
17.43 \\
20.49 \\
23.54\end{array}$ \\
\hline $\begin{array}{r}900 \\
1000 \\
1100 \\
1200 \\
1300\end{array}$ & $\begin{array}{l}26.40 \\
29.52 \\
32.72 \\
36.01 \\
39.43\end{array}$ & $\begin{array}{l}26.41 \\
29.53 \\
32.70 \\
35.97 \\
39.36\end{array}$ & $\begin{array}{l}\text { 26. } 42 \\
29.54 \\
32.72 \\
36.00 \\
39.40\end{array}$ & $\begin{array}{l}\text { 26. } 31 \\
29.41 \\
32.60 \\
35.88 \\
39.28\end{array}$ & $\begin{array}{l}26.38 \\
29.51 \\
32.72 \\
36.00 \\
39.40\end{array}$ & $\begin{array}{l}26.50 \\
29.63 \\
32.82 \\
36.11 \\
39.52\end{array}$ & $\begin{array}{l}26.37 \\
29.50 \\
32.70 \\
35.98 \\
39.40\end{array}$ & $\begin{array}{l}26.32 \\
29.45 \\
32.65 \\
35.94 \\
39.36\end{array}$ & $\begin{array}{l}26.42 \\
29.55 \\
32.75 \\
36.05 \\
39.46\end{array}$ & $\begin{array}{l}\text { 26. } 60 \\
29.71 \\
32.89 \\
36.18 \\
39.58\end{array}$ \\
\hline $\begin{array}{l}1400 \\
1500 \\
1600 \\
1700 \\
1800\end{array}$ & $\begin{array}{l}42.96 \\
46.53 \\
50.05 \\
53.34 \\
56.64\end{array}$ & $\begin{array}{l}42.84 \\
46.30 \\
49.64 \\
52.86 \\
56.12\end{array}$ & $\begin{array}{l}42.92 \\
46.49 \\
50.05 \\
53.31 \\
56.59\end{array}$ & $\begin{array}{l}42.81 \\
46.44 \\
50.10 \\
53.55 \\
56.91\end{array}$ & $\begin{array}{l}\text { 42. } 89 \\
\text { 46. } 37 \\
\text { 49. } 83 \\
53.10 \\
56.38\end{array}$ & $\begin{array}{l}43.05 \\
46.67 \\
50.34 \\
53.87 \\
57.16\end{array}$ & $\begin{array}{l}42.92 \\
46.51 \\
50.08 \\
53.44 \\
56.74\end{array}$ & $\begin{array}{l}42.89 \\
46.48 \\
49.98 \\
53.40 \\
56.73\end{array}$ & $\begin{array}{l}42.95 \\
46.47 \\
49.99 \\
53.52 \\
57.04\end{array}$ & $\begin{array}{l}\text { 43. } 11 \\
46.73 \\
50.38 \\
53.86 \\
57.17\end{array}$ \\
\hline
\end{tabular}

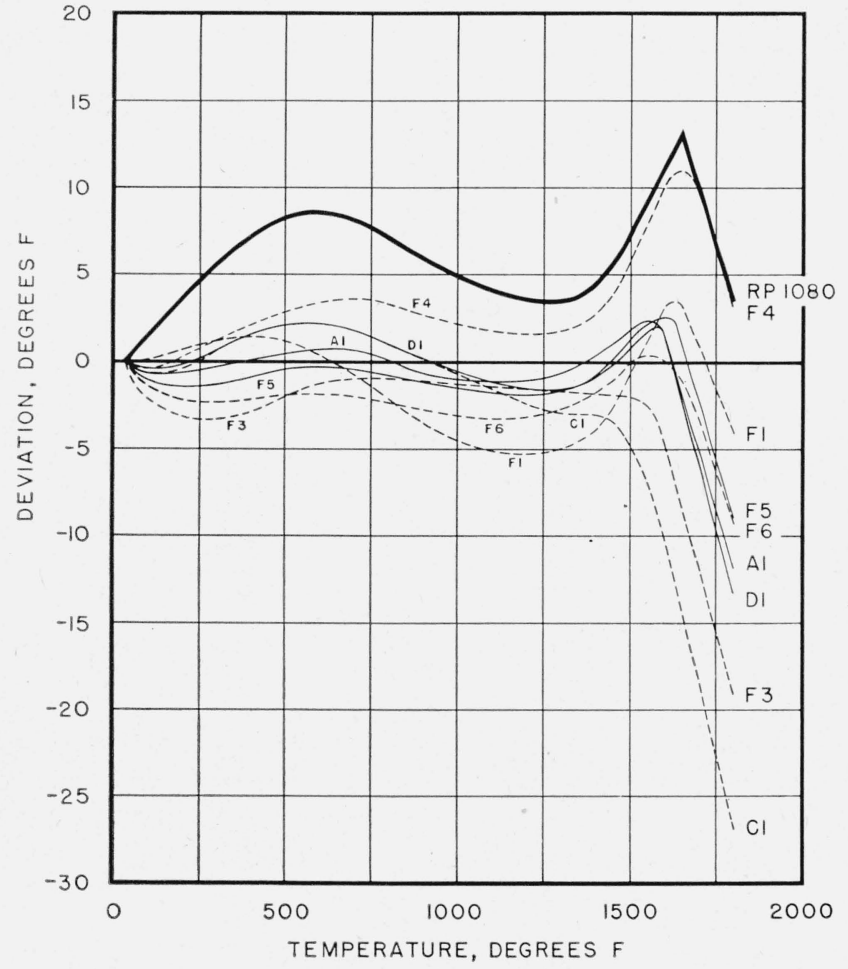

FIGURE 1. Deviation of $S A M A$ iron-constantan thermocouples and RP1080 table from the 1913 table.

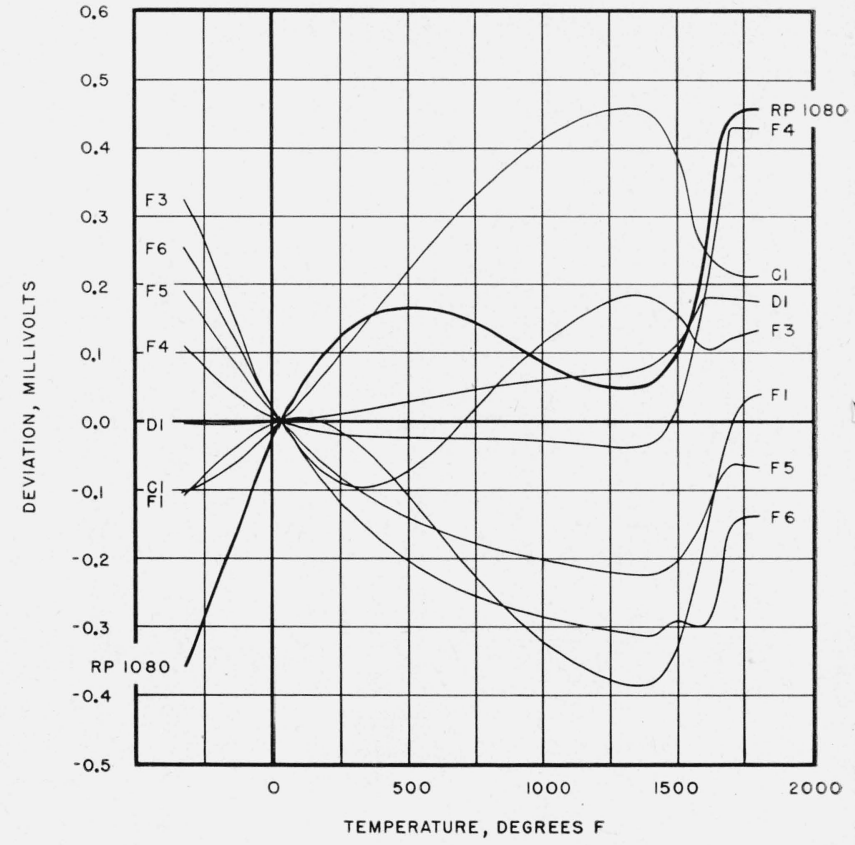

FIgURE 2. Deviation of SAMA iron samples and RP1080 iron from iron sample $A-1$. 


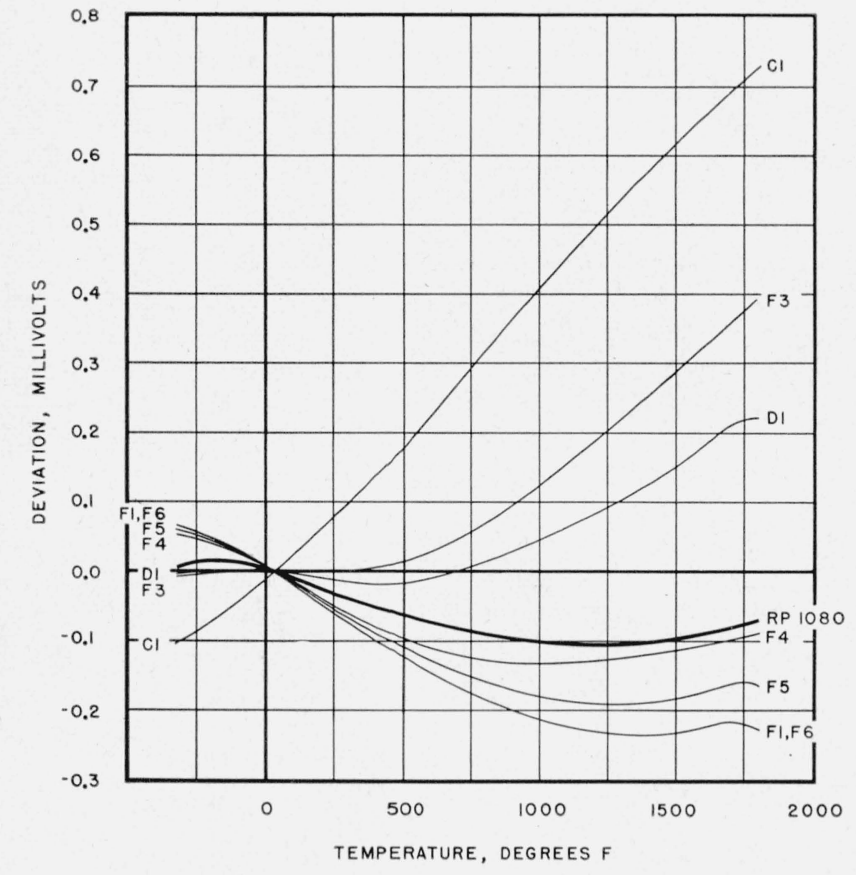

Figure 3. Deviation of SAMA constantan samples and RP1080 constantan from constantan sample A-1.

sent the data for iron versus platinum and constantan versus platinum given in [3]. The 1913 table was for iron versus constantan only and, consequently, the corresponding data for the individual elements versus platinum are not available for inclusion in figures 2 and 3 . The constantan marked "F-1, F-6" was a single sample intended for use in combination with either the $\mathrm{F}-1$ or $\mathrm{F}-6$ iron sample. In figure 4 similar plots for the completed thermocouples are given. In preparing these figures, the 1913 and RP1080 tables were adjusted to the emf units and temperature scale used in this investigation and currently in use at this Bureau. These are the absolute system of electrical units [7] and the International Temperature Scale of 1948 [8]. One absolute volt is equal to 0.99967 international volt

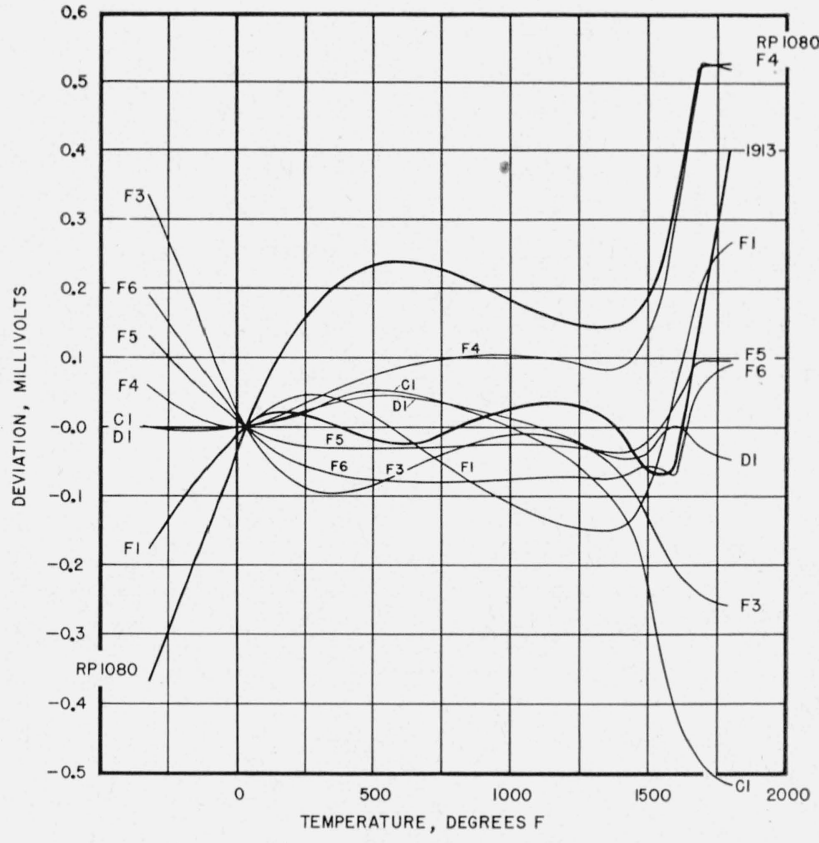

Figure 4. Deviations of SAMA iron-constantan thermocouples, the 1913 table, and the RP1080 table from thermocouple $A-1$.

(U. S.). The differences between the International Temperature Scales of 1948 and 1927 are not more than $0.8 \mathrm{deg} \mathrm{F}$ in the range of this investigation [9] and so are nearly negligible.

The differences in shape of the various curves in figure 4 are mainly due to the iron elements because the deviations of the constantan elements from each other are approximately linear. It is well known that thermal emf depends both on chemical composition and on the degree of strain. In hope of gaining some insight into the differences among the various thermocouples, the iron samples were analyzed chemically, and their hardnesses were determined. This work was done by the Chemistry and Metallurgy Divisions of the Bureau. The results are given in tables 4 and 5 .

TABLE 4. Chemical and spectrographic analyses of iron samples

[Values are given in percent]

\begin{tabular}{|c|c|c|c|c|c|c|c|c|c|}
\hline Sample & $\mathrm{C}$ & Mn & $\mathrm{P}$ & $\mathrm{S}$ & $\mathrm{Cu}$ & $\mathrm{Si}{ }^{*}$ & $\mathrm{Ni} *$ & $\mathrm{Cr} *$ & $\mathrm{Sn} *$ \\
\hline $\begin{array}{l}\text { A-1 } \\
\text { C-1 } \\
\text { D-1 } \\
\text { F-1 } \\
\text { F-3 } \\
\text { F-4 } \\
\text { F-5 } \\
\text { F-6 }\end{array}$ & $\begin{array}{r}0.07 \\
.11 \\
.04 \\
.02 \\
.08 \\
.02 \\
.06 \\
.05\end{array}$ & $\begin{array}{r}0.25 \\
.38 \\
.29 \\
.03 \\
.43 \\
.23 \\
.21 \\
.22\end{array}$ & $\begin{array}{r}0.015 \\
.005 \\
.009 \\
.004 \\
.080 \\
.011 \\
.006 \\
.006\end{array}$ & $\begin{array}{r}0.031 \\
.031 \\
.024 \\
.029 \\
.028 \\
.016 \\
.020 \\
.018\end{array}$ & $\begin{array}{l}0.12 \\
.054 \\
.14 \\
.15 \\
.018 \\
.023 \\
.022 \\
.022\end{array}$ & $\begin{array}{r}<0.01 \\
<.01 \\
<.01 \\
<.01 \\
.02 \\
<.01 \\
.01 \\
<.01\end{array}$ & $\begin{array}{r}0.044 \\
.030 \\
.042 \\
.039 \\
.011 \\
.014 \\
.013 \\
.012\end{array}$ & $\begin{array}{r}0.015 \\
.016 \\
.016 \\
.025 \\
<.01 \\
<.01 \\
<.01 \\
<.01\end{array}$ & $\begin{array}{r}<0.01 \\
<.01 \\
<.01 \\
<.01 \\
.01 \\
<.01 \\
<.01 \\
.01\end{array}$ \\
\hline
\end{tabular}

*Spectographic determination. 
TABLE 5. Results of hardness measurements on samples of iron wire

\begin{tabular}{|c|c|c|}
\hline Sample & $\begin{array}{c}\text { Vickers } \\
\text { number* }\end{array}$ & $\begin{array}{c}\text { Equivalent } \\
\text { Rockwell B } \\
\text { number }\end{array}$ \\
\hline A-1 & 99.8 & 55 \\
C-1 & 106 & 59.5 \\
D-1 & 138 & 76 \\
F-1 & 127 & 71 \\
F-3 & 210 & 94 \\
F-4 & 83.6 & 39 \\
F-5 & 138 & 76 \\
F-6 & 131 & 73 \\
\hline
\end{tabular}

*Determinations were made with a $10-\mathrm{kg}$ load applied through a square-based diamond-pyramid indenter.

\section{Discussion}

The sharp changes in the slopes of the various curves in figure 1 at about $1,650^{\circ} \mathrm{F}$ are thought to be due to the 1913 table having been based in this region on an extrapolation that neglected the effect of the abrupt change in thermoelectric power of iron at the $\alpha-\gamma$ transition. At lower temperatures the various curves show a characteristic undulation. It is not known to what extent this is due to errors in the original 1913 calibration and to what extent to differences between the chemical compositions characteristic of iron used for thermocouples in 1913 and at present.

It was hardly to be expected that the curves of figure 2 would be fully interpretable, inasmuch as the research was designed to test these commercial materials in the "as received" condition, and did not provide for that control of the variables of chemical composition and heat treatment that would be necessary for a fundamental understanding of the results.

The quantum theory of metals leads to the correct predictions that iron is thermoelectrically positive to platinum and that the effect of small percentages of copper on the thermoelectric power is opposite in sign to the effect of manganese. However, a detailed explanation of the features shown in figure 2 is beyond the present scope of theory. Nevertheless, a few generalizations may be noted from the data.

Roeser and Dahl [3] showed that the 1913 table could be approximated by using iron wires having several tenths percent of $\mathrm{Mn}$, whereas the samples of which RP1080 was characteristic contained less than 0.1 percent of Mn. The effects of small percentages of the minor elements that are common in commercial iron on the thermoelectric power of iron have been investigated by Finch [10], who described several compositions of iron that can be used in thermocouples. Finch showed that the thermoelectric power of iron at $500^{\circ} \mathrm{C}\left(932^{\circ} \mathrm{F}\right)$ is increased by additions of $\mathrm{Cr}, \mathrm{S}$, or $\mathrm{Mn}$ and decreased by $\mathrm{Sn}$, $\mathrm{Si}, \mathrm{P}, \mathrm{Ni}$, and (in percentages greater than 0.10 ) $\mathrm{Cu}$, whereas the effect of carbon is negligible. It will be noted that the curve for iron sample $\mathrm{F}-1$ is similar in shape to that for RP1080 iron, and, indeed, its manganese content of only 0.03 percent marks it as an RP1080-type iron. In the other iron samples, manganese is the principal minor element, and the thermal emf at $932^{\circ} \mathrm{F}$ (see fig. 2), with minor exceptions, increases with the manganese concentration, as would be predicted from the work of Finch.

The bunching of the curves in the gamma region above $1,650^{\circ} \mathrm{F}$ may be the result of differences in electronic band-structure in alpha and gamma iron. However, the steep rise of $\mathrm{F}-1$ and $\mathrm{F}-4$ is exceptional. These samples were lowest in carbon (0.02 percent), whereas the samples showing the opposite behavior, $\mathrm{C}-1$ and $\mathrm{F}-3$, were highest and second highest, respectively, in carbon content $(0.11$ and 0.08 percent). The effect thus may be connected with the solution of carbon in the gamma-phase iron. A study of the phases present initially was not made, and so no positive statement may be made on this point.

Dahl has shown $[11 ; 5$, p. 1238$]$ that thermocouple iron decreases in thermoelectric power on heating at temperatures above $1,200^{\circ} \mathrm{F}$. However, the annealing of high-purity iron increases the thermoelectric power, so that it appears that the drift in the thermal emf of the iron elements of thermocouples at high temperatures is primarily due to phase changes and chemical changes, and that relief of strain is not an important factor in this drift.

The unique shape of curve F-3 may be related to any of the following factors: (1) Its manganese content was highest of all (0.43 percent); (2) Its phosphorus content was very much higher than that of the other samples; (3) Its hardness was unusually high.

The curves in figure 3 show the approximately linear deviation that is characteristic of constantan [3].

The maximum differences among the iron samples and also among the constantan samples amounted to about $0.8 \mathrm{mv}$ at $1,400^{\circ} \mathrm{F}$, which is equivalent to about $20 \mathrm{deg} \mathrm{F}$ in the indication of an iron-constantan thermocouple. In addition, there were marked differences in the curve shape for the iron samples. Nevertheless, the calibrations of the completed thermocouples fell within a satisfactorily narrow band up to $1,500^{\circ} \mathrm{F}$. The width of this band on either side of the relation for thermocouple $A-1$ was approximately equivalent to commercial tolerances for the iron-constantan thermocouple, thus indicating the practicality of the $\mathrm{A}-1$ relation for a commercial standard. However, the large differences among the wires of a given kind illustrate the impracticality of establishing standards for the emf of the individual elements (against platinum) as has been done for the elements of all the other common thermocouples.

The deviations of the thermocouples below $32^{\circ} \mathrm{F}$ are quite large in terms of temperature, which indicates the necessity for care in establishing the calibrations of thermocouples in this range. However, the deviations in emf are nearly linear, so that relatively few calibration temperatures need be used. 


\section{Reference Table for 1913-type Iron-Con- stantan Thermocouples}

As a result of this investigation, the Thermocouple Calibration Curves Committee, Recorder-Controller Section, SAMA, has recommended adoption of the temperature electromotive force relationship of thermocouple $A-1$ as a tentative standard. Because of the known instability of iron-constantan thermocouples above $1,600^{\circ} \mathrm{F}$, and also because of the large increase in deviation of the thermocouples from each other in this region, the upper limit of the standard has been set at $1,600^{\circ} \mathrm{F}$. (Manufacturers of this thermocouple do not recommend its use above $1,400^{\circ}$ to $1,500^{\circ} \mathrm{F}$, except in special circumstances.) The differences between the $\mathrm{A}-1$ relationship and the 1913 table, when both are expressed in consistent electrical units and temperature scale, are given in table 6 .

TABLE 6. Differences between $A-1$ and 1913 tables for ironconstantan thermocouples

\begin{tabular}{|c|c|c|}
\hline $\begin{array}{l}\text { Temper- } \\
\text { ature }\end{array}$ & \multicolumn{2}{|c|}{$\begin{array}{c}\text { Emf A-1 table minus emf } \\
1913 \text { table }\end{array}$} \\
\hline $\begin{array}{r}{ }^{\circ} F \\
32 \\
100 \\
200 \\
300 \\
400 \\
500 \\
600 \\
700 \\
800 \\
900 \\
1,000 \\
1,100 \\
1,200 \\
1,300 \\
1,400 \\
1,500 \\
1,600\end{array}$ & $\begin{array}{l}\text { Millivolts } \\
0.00 \\
-.02 \\
-.01 \\
-.01 \\
+.01 \\
+.02 \\
+.01 \\
+.02 \\
.00 \\
-.02 \\
-.03 \\
-.03 \\
-.04 \\
-.03 \\
+.01 \\
+.06 \\
+.06\end{array}$ & $\begin{array}{c}\text { Equivaient } \\
\text { degrees F } \\
0.0 \\
-.7 \\
-.3 \\
-.3 \\
+.3 \\
+.7 \\
+.3 \\
+.7 \\
-.0 \\
-.7 \\
-.9 \\
-.9 \\
-1.2 \\
-0.9 \\
+.3 \\
+1.7 \\
+1.7\end{array}$ \\
\hline
\end{tabular}

In December 1950, preliminary results of this investigation were summarized in a published article [12]. In this article it was pointed out that the temperature-emf relationship of sample $A-1$ was favored for the proposed new SAMA standard. In order to determine whether or not the $\mathrm{A}-1$ relationship would be acceptable as an industry-wide standard, replacing not merely the 1913 table but also the RP1080 table, answers to the following questions were solicited: (1) Is industry-wide standardization on a single reference table for iron-constantan desirable? (2) Is the 1913 table, or a close approximation to it, acceptable for this purpose? (3) What degree of hardship will be occasioned by abandonment of the RP1080 table?

The replies received were uniformly favorable to a single industry-wide standard. Users and suppliers of 1913-type thermocouples were uniformly favorable to the proposed SAMA standard. However, most of the replies received from users and suppliers of solely
RP1080-type thermocouples indicated that it would not be practicable for them to change to the proposed SAMA standard. It is important to point out that the change from RP1080-type to A-1-type thermocouples would require alterations to most of the associated indicating equipment, whereas the difference between the 1913 and $\mathrm{A}-1$ relationships is much smaller and is less than commercial tolerances for this thermocouple.

Thus it appears that at least two standards, the SAMA table $(\mathrm{A}-1)$ and the RP1080 table, will coexist in the immediate future. Most commercial production of iron-constantan will probably be based on the SAMA table, as it has been based on the 1913 table in the past. On the other hand, one of the principal fields in which the RP1080 standard is dominant-namely, in piston-engined military aircraft - is declining in importance.

In order to make the $A-1$ relationship useful, it has been expanded into four tables, numbers $7,8,9$, and 10. Before doing this, additional samples of the A lot were calibrated as a check against gross errors. 'The differences between these and the calibration of A-1 were within the limit of error of the calibration process. In table 7 , the desired function for the region from $-320^{\circ}$ to $0^{\circ} \mathrm{F}$ was obtained at intervals of $1 \mathrm{deg}$ by the method of divided differences. For the range from $0^{\circ}$ to $+1600^{\circ} \mathrm{F}$, the LaGrange polynomial was used. Linear interpolation, either direct or inverse, was then performed on this table to obtain the remaining tables. The preparation of tables 7 to 10 was carried out by the Applied Mathematics Division of the Bureau.

The thermoelectric measurements below $32^{\circ} \mathrm{F}$ were made in the Thermometry Laboratory by Ruth C. Gallman and Eugenia Thomas. It is a pleasure to acknowledge the advice given by Wm. F. Roeser and also the cooperation of the various members of the Thermocouple Calibration Curves Committee of SAMA and their chairman, Edward J. Albert.

\section{References}

[1] Wm. F. Roeser and H. T. Wensel, BS J. Research 10, 275 (1933) RP530.

[2] Wm. F. Roeser, A. I. Dahl, and G. J. Gowens, J. Research NBS 14, 239 (1935) RP767.

[3] Wm. F. Roeser and A. I. Dahl, J. Research NBS 20, 337 (1938) RP1080.

[4] Wm. F. Roeser and H. T. Wensel, J. Research NBS 14, 263 (1935) RP768.

[5] Temperature, its measurement and control in science and industry, p. 297 (Reinhold Publishing Corp., New York, N. Y., 1941)

[6] Russel B. Scott, J. Research NBS 25, 459 (1940) RP1339.

[7] NBS Circular 459, May 15, 1947.

[8] H. F. Stimson, J. Research NBS 42, 209 (1949) RP1962.

[9] Robert J. Corruccini, J. Research NBS 43, 133 (1949) RP2014.

[10] Donald I. Finch, U. S. Patent 2325759 (August 3, 1943).

[11] A. I. Dahl, J. Research NBS, 24, 205 (1940) RP1278.

[12] NBS Technical News Bulletin 34, 174 (December 1950). 
Table 7. Iron-Constantan Thermocouples

(Emf in Absolute Millivolts. Temperatures in Degrees F. * Reference Junctions at $32^{\circ}$ F.)

\begin{tabular}{|c|c|c|c|c|c|c|c|c|c|c|c|c|}
\hline \multirow[t]{2}{*}{${ }^{\circ} \mathrm{F}$} & 0 & 1 & 2 & 3 & 4 & 5 & 6 & 7 & 8 & 9 & 10 & \multirow[t]{2}{*}{${ }^{\circ} \mathrm{F}$} \\
\hline & \multicolumn{11}{|c|}{ Millivolts } & \\
\hline $\begin{array}{l}-310 \\
-300\end{array}$ & $\begin{array}{l}-7.66 \\
-7.52\end{array}$ & $\begin{array}{l}-7.68 \\
-7.54\end{array}$ & $\begin{array}{l}-7.69 \\
-7.55\end{array}$ & $\begin{array}{l}-7.70 \\
-7.57\end{array}$ & $\begin{array}{l}-7.71 \\
-7.58\end{array}$ & $\begin{array}{l}-7.73 \\
-7.59\end{array}$ & $\begin{array}{l}-7.74 \\
-7.61\end{array}$ & $\begin{array}{l}-7.75 \\
-7.62\end{array}$ & $\begin{array}{l}-7.76 \\
-7.64\end{array}$ & $\begin{array}{l}-7.78 \\
-7.65\end{array}$ & $\begin{array}{l}-7.79 \\
-7.66\end{array}$ & $\begin{array}{l}-310 \\
-300\end{array}$ \\
\hline $\begin{array}{l}-290 \\
-280 \\
-270\end{array}$ & $\begin{array}{l}-7.38 \\
-7.22 \\
-7.06\end{array}$ & $\begin{array}{l}-7.39 \\
-7.24 \\
-7.07\end{array}$ & $\begin{array}{l}-7.40 \\
-7.25 \\
-7.09\end{array}$ & $\begin{array}{l}-7.42 \\
-7.27 \\
-7.11\end{array}$ & $\begin{array}{l}-7.44 \\
-7.28 \\
-7.12\end{array}$ & $\begin{array}{l}-7.45 \\
-7.30 \\
-7.14\end{array}$ & $\begin{array}{l}-7 \cdot 46 \\
-7.31 \\
-7.15\end{array}$ & $\begin{array}{l}-7.48 \\
-7.33 \\
-7.17\end{array}$ & $\begin{array}{l}-7.49 \\
-7.34 \\
-7.19\end{array}$ & $\begin{array}{l}-7.51 \\
-7.36 \\
-7.20\end{array}$ & $\begin{array}{l}-7.52 \\
-7.38 \\
-7.22\end{array}$ & $\begin{array}{l}-290 \\
-280 \\
-270\end{array}$ \\
\hline $\begin{array}{l}-260 \\
-250 \\
-240\end{array}$ & $\begin{array}{l}-6.89 \\
-6.71 \\
-6.53\end{array}$ & $\begin{array}{l}-6.90 \\
-6.73 \\
-6.55\end{array}$ & $\begin{array}{l}-6.92 \\
-6.75 \\
-6.57\end{array}$ & $\begin{array}{l}-6.94 \\
-6.77 \\
-6.59\end{array}$ & $\begin{array}{l}-6.96 \\
-6.78 \\
-6.61\end{array}$ & $\begin{array}{l}-6.97 \\
-6.80 \\
-6.62\end{array}$ & $\begin{array}{l}-6.99 \\
-6.82 \\
-6.64\end{array}$ & $\begin{array}{l}-7.01 \\
-6.84 \\
-6.66\end{array}$ & $\begin{array}{l}-7.02 \\
-6.85 \\
-6.68\end{array}$ & $\begin{array}{l}-7.04 \\
-6.87 \\
-6.70\end{array}$ & $\begin{array}{l}-7.06 \\
-6.89 \\
-6.71\end{array}$ & $\begin{array}{l}-260 \\
-250 \\
-240\end{array}$ \\
\hline $\begin{array}{l}-230 \\
-220 \\
-210\end{array}$ & $\begin{array}{l}-6.35 \\
-6.16 \\
-5.96\end{array}$ & $\begin{array}{l}-6.37 \\
-6.18 \\
-5.98\end{array}$ & $\begin{array}{l}-6.38 \\
-6.19 \\
-6.00\end{array}$ & $\begin{array}{l}-6.40 \\
-6.21 \\
-6.02\end{array}$ & $\begin{array}{l}-6.42 \\
-6.23 \\
-6.04\end{array}$ & $\begin{array}{l}-6.44 \\
-6.25 \\
-6.06\end{array}$ & $\begin{array}{l}-6.46 \\
-6.27 \\
-6.08\end{array}$ & $\begin{array}{l}-6.48 \\
-6.29 \\
-6.10\end{array}$ & $\begin{array}{l}-6.50 \\
-6.31 \\
-6.12\end{array}$ & $\begin{array}{l}-6.52 \\
-6.33 \\
-6.14\end{array}$ & $\begin{array}{l}-6.53 \\
-6.35 \\
-6.16\end{array}$ & $\begin{array}{l}-230 \\
-220 \\
-210\end{array}$ \\
\hline-200 & .76 & -5.78 & -5.80 & -5.82 & -5.84 & -5.86 & -5.88 & $-5 \cdot 90$ & -5.92 & -5.94 & -5.96 & -200 \\
\hline $\begin{array}{l}-190 \\
-180 \\
-170\end{array}$ & $\begin{array}{l}-5 \cdot 55 \\
-5 \cdot 34 \\
-5 \cdot 12\end{array}$ & $\begin{array}{l}-5.57 \\
-5.36 \\
-5.14\end{array}$ & $\begin{array}{l}-5.59 \\
-5.38 \\
-5.16\end{array}$ & $\begin{array}{l}-5.61 \\
-5.40 \\
-5.19\end{array}$ & $\begin{array}{l}-5.63 \\
-5.42 \\
-5.21\end{array}$ & $\begin{array}{l}-5.65 \\
-5.44 \\
-5.23\end{array}$ & $\begin{array}{l}-5.67 \\
-5.46 \\
-5.25\end{array}$ & $\begin{array}{l}-5.70 \\
-5.49 \\
-5.27\end{array}$ & $\begin{array}{l}-5.72 \\
-5.51 \\
-5.30\end{array}$ & $\begin{array}{l}-5.74 \\
-5.53 \\
-5.32\end{array}$ & $\begin{array}{l}-5.76 \\
-5.55 \\
-5.34\end{array}$ & $\begin{array}{l}-190 \\
-180 \\
-170\end{array}$ \\
\hline $\begin{array}{l}-160 \\
-150 \\
-140\end{array}$ & $\begin{array}{l}-4.90 \\
-4.68 \\
-4.44\end{array}$ & $\begin{array}{l}-4.92 \\
-4.70 \\
-4.47\end{array}$ & $\begin{array}{l}-4.94 \\
-4.72 \\
-4.49\end{array}$ & $\begin{array}{l}-4.97 \\
-4.74 \\
-4.51\end{array}$ & $\begin{array}{l}-4.99 \\
-4.76 \\
-4.54\end{array}$ & $\begin{array}{l}-5.01 \\
-4.79 \\
-4.56\end{array}$ & $\begin{array}{l}-5.03 \\
-4.81 \\
-4.58\end{array}$ & $\begin{array}{l}-5.06 \\
-4.83 \\
-4.61\end{array}$ & $\begin{array}{l}-5.08 \\
-4.86 \\
-4.63\end{array}$ & $\begin{array}{l}-5.10 \\
-4.88 \\
-4.65\end{array}$ & $\begin{array}{l}-5.12 \\
-4.90 \\
-4.68\end{array}$ & $\begin{array}{l}-160 \\
-150 \\
-140\end{array}$ \\
\hline $\begin{array}{l}-130 \\
-120 \\
-110\end{array}$ & $\begin{array}{l}-4.21 \\
-3.97 \\
-3.73\end{array}$ & $\begin{array}{l}-4.23 \\
-4.00 \\
-3.76\end{array}$ & $\begin{array}{l}-4.26 \\
-4.02 \\
-3.78\end{array}$ & $\begin{array}{l}-4.28 \\
-4.04 \\
-3.81\end{array}$ & $\begin{array}{l}-4.30 \\
-4.07 \\
-3.83\end{array}$ & $\begin{array}{l}-4.33 \\
-4.09 \\
-3.85\end{array}$ & $\begin{array}{l}-4.35 \\
-4.12 \\
-3.88\end{array}$ & $\begin{array}{l}-4.38 \\
-4.14 \\
-3.90\end{array}$ & $\begin{array}{l}-4.40 \\
-4.16 \\
-3.93\end{array}$ & $\begin{array}{l}-4.42 \\
-4.19 \\
-3.95\end{array}$ & $\begin{array}{l}-4.44 \\
-4.21 \\
-3.97\end{array}$ & $\begin{array}{l}-130 \\
-120 \\
-110\end{array}$ \\
\hline-100 & -3.49 & -3.51 & -3.54 & -3.56 & -3.59 & -3.61 & -3.64 & -3.66 & -3.68 & -3.71 & -3.73 & -100 \\
\hline $\begin{array}{l}-90 \\
-80 \\
-70\end{array}$ & $\begin{array}{l}-3.24 \\
-2.99 \\
-2.74\end{array}$ & $\begin{array}{l}-3.27 \\
-3.02 \\
-2.76\end{array}$ & $\begin{array}{l}-3.29 \\
-3.04 \\
-2.79\end{array}$ & $\begin{array}{l}-3.32 \\
-3.07 \\
-2.81\end{array}$ & $\begin{array}{l}-3.34 \\
-3.09 \\
-2.84\end{array}$ & $\begin{array}{l}-3.36 \\
-3.12 \\
-2.86\end{array}$ & $\begin{array}{l}-3.39 \\
-3.14 \\
-2.89\end{array}$ & $\begin{array}{l}-3.41 \\
-3.17 \\
-2.92\end{array}$ & $\begin{array}{l}-3.44 \\
-3.19 \\
-2.94\end{array}$ & $\begin{array}{l}-3.46 \\
-3.22 \\
-2.97\end{array}$ & $\begin{array}{l}-3.49 \\
-3.24 \\
-2.99\end{array}$ & $\begin{array}{l}-90 \\
-80 \\
-70\end{array}$ \\
\hline $\begin{array}{l}-60 \\
-50 \\
-40\end{array}$ & $\begin{array}{l}-2.48 \\
-2.22 \\
-1.96\end{array}$ & $\begin{array}{l}-2.51 \\
-2.25 \\
-1.99\end{array}$ & $\begin{array}{l}-2.53 \\
-2.27 \\
-2.01\end{array}$ & $\begin{array}{l}-2.56 \\
-2.30 \\
-2.04\end{array}$ & $\begin{array}{l}-2.58 \\
-2.33 \\
-2.06\end{array}$ & $\begin{array}{l}-2.61 \\
-2.35 \\
-2.09\end{array}$ & $\begin{array}{l}-2.64 \\
-2.38 \\
-2.12\end{array}$ & $\begin{array}{l}-2.66 \\
-2.40 \\
-2.14\end{array}$ & $\begin{array}{l}-2.69 \\
-2.43 \\
-2.17\end{array}$ & $\begin{array}{l}-2.71 \\
-2.46 \\
-2.20\end{array}$ & $\begin{array}{l}-2.74 \\
-2.48 \\
-2.22\end{array}$ & $\begin{array}{l}-60 \\
-50 \\
-40\end{array}$ \\
\hline $\begin{array}{l}-30 \\
-20 \\
-10\end{array}$ & $\begin{array}{l}-1.70 \\
-1.43 \\
-1.16\end{array}$ & $\begin{array}{l}-1.72 \\
-1.46 \\
-1.19\end{array}$ & $\begin{array}{l}-1.75 \\
-1.48 \\
-1.21\end{array}$ & $\begin{array}{l}-1.78 \\
-1.51 \\
-1.24\end{array}$ & $\begin{array}{l}-1.80 \\
-1.54 \\
-1.27\end{array}$ & $\begin{array}{l}-1.83 \\
-1.56 \\
-1.29\end{array}$ & $\begin{array}{l}-1.86 \\
-1.59 \\
-1.32\end{array}$ & $\begin{array}{l}-1.88 \\
-1.62 \\
-1.35\end{array}$ & $\begin{array}{l}-1.91 \\
-1.64 \\
-1.38\end{array}$ & $\begin{array}{l}-1.94 \\
-1.67 \\
-1.40\end{array}$ & $\begin{array}{l}-1.96 \\
-1.70 \\
-1.43\end{array}$ & $\begin{array}{l}-30 \\
-20 \\
-10\end{array}$ \\
\hline$(-) 0$ & -.89 & -.91 & -.94 & -.97 & -1.00 & -1.02 & -1.05 & -1.08 & -1.10 & -1.13 & -1.16 & $(-) 0$ \\
\hline$(+) 0$ & -.89 & -.86 & -.83 & -.80 & -.78 & -.75 & -.72 & -.70 & -.67 & -.64 & -.61 & $(+) 0$ \\
\hline
\end{tabular}

*Based on the International Temperature Scale of 1948 . 
Table 7. Iron-Constantan Thermocouples-Continued

(Emf in Absolute Millivolts. Temperatures in Degrees F. ${ }^{*}$ Reference Junctions at $32^{\circ}$ F.)

\begin{tabular}{|c|c|c|c|c|c|c|c|c|c|c|c|c|}
\hline \multirow[t]{2}{*}{${ }^{\circ} \mathrm{F}$} & 0 & 1 & 2 & 3 & 4 & 5 & 6 & 7 & 8 & 9 & 10 & \multirow[t]{2}{*}{${ }^{\circ} \mathrm{F}$} \\
\hline & \multicolumn{11}{|c|}{ Millivolts } & \\
\hline$(+) 0$ & -.89 & -.86 & -.83 & -.80 & -.78 & -.75 & -.72 & -.70 & -.67 & -.64 & -.61 & $(+) 0$ \\
\hline $\begin{array}{l}10 \\
20 \\
30\end{array}$ & $\begin{array}{l}-.61 \\
-.34 \\
-.06\end{array}$ & $\begin{array}{l}-.58 \\
-.31 \\
-.03\end{array}$ & $\begin{array}{l}-.56 \\
-.28 \\
-.00\end{array}$ & $\begin{array}{r}-.53 \\
-.25 \\
.03\end{array}$ & $\begin{array}{r}-.50 \\
-.22 \\
.05\end{array}$ & $\begin{array}{r}-.48 \\
-.20 \\
.08\end{array}$ & $\begin{array}{r}-.45 \\
-.17 \\
.11\end{array}$ & $\begin{array}{r}-.42 \\
-.14 \\
.14\end{array}$ & $\begin{array}{r}-.39 \\
-.11 \\
.17\end{array}$ & $\begin{array}{r}-.36 \\
-.09 \\
.19\end{array}$ & $\begin{array}{r}-.34 \\
-.06 \\
.22\end{array}$ & $\begin{array}{l}10 \\
20 \\
30\end{array}$ \\
\hline $\begin{array}{l}40 \\
50 \\
60\end{array}$ & $\begin{array}{l}.22 \\
.50 \\
.79\end{array}$ & $\begin{array}{l}.25 \\
.53 \\
.82\end{array}$ & $\begin{array}{l}.28 \\
.56 \\
.84\end{array}$ & $\begin{array}{l}.31 \\
.59 \\
.87\end{array}$ & $\begin{array}{l}.34 \\
.62 \\
.90\end{array}$ & $\begin{array}{l}.36 \\
.65 \\
.93\end{array}$ & $\begin{array}{l}.39 \\
.67 \\
.96\end{array}$ & $\begin{array}{l}.42 \\
.70 \\
.99\end{array}$ & $\begin{array}{r}.45 \\
.73 \\
1.02\end{array}$ & $\begin{array}{r}.48 \\
.76 \\
1.04\end{array}$ & $\begin{array}{r}.50 \\
.79 \\
1.07\end{array}$ & $\begin{array}{l}40 \\
50 \\
60\end{array}$ \\
\hline $\begin{array}{l}70 \\
80 \\
90\end{array}$ & $\begin{array}{l}1.07 \\
1.36 \\
1.65\end{array}$ & $\begin{array}{l}1.10 \\
1.39 \\
1.68\end{array}$ & $\begin{array}{l}1.13 \\
1.42 \\
1.71\end{array}$ & $\begin{array}{l}1.16 \\
1.45 \\
1.74\end{array}$ & $\begin{array}{l}1.19 \\
1.48 \\
1.77\end{array}$ & $\begin{array}{l}1.22 \\
1.51 \\
1.80\end{array}$ & $\begin{array}{l}1.25 \\
1.54 \\
1.83\end{array}$ & $\begin{array}{l}1.28 \\
1.56 \\
1.85\end{array}$ & $\begin{array}{l}1.30 \\
1.59 \\
1.88\end{array}$ & $\begin{array}{l}1.33 \\
1.62 \\
1.91\end{array}$ & $\begin{array}{l}1.36 \\
1.65 \\
1.94\end{array}$ & $\begin{array}{l}70 \\
80 \\
90\end{array}$ \\
\hline 100 & 1.94 & 1.97 & 2.00 & 2.03 & 2.06 & 2.09 & 2.12 & 2.14 & 2.17 & 2.20 & 2.23 & 100 \\
\hline $\begin{array}{l}110 \\
120 \\
130\end{array}$ & $\begin{array}{l}2.23 \\
2.52 \\
2.82\end{array}$ & $\begin{array}{l}2.26 \\
2.55 \\
2.85\end{array}$ & $\begin{array}{l}2.29 \\
2.58 \\
2.88\end{array}$ & $\begin{array}{l}2.32 \\
2.61 \\
2.91\end{array}$ & $\begin{array}{l}2.35 \\
2.64 \\
2.94\end{array}$ & $\begin{array}{l}2.38 \\
2.67 \\
2.97\end{array}$ & $\begin{array}{l}2.41 \\
2.70 \\
3.00\end{array}$ & $\begin{array}{l}2.44 \\
2.73 \\
3.03\end{array}$ & $\begin{array}{l}2.47 \\
2.76 \\
3.06\end{array}$ & $\begin{array}{l}2.50 \\
2.79 \\
3.08\end{array}$ & $\begin{array}{l}2.52 \\
2.82 \\
3.11\end{array}$ & $\begin{array}{l}110 \\
120 \\
130\end{array}$ \\
\hline $\begin{array}{l}140 \\
150 \\
160\end{array}$ & $\begin{array}{l}3.11 \\
3.41 \\
3.71\end{array}$ & $\begin{array}{l}3.14 \\
3.44 \\
3.74\end{array}$ & $\begin{array}{l}3.17 \\
3.47 \\
3.77\end{array}$ & $\begin{array}{l}3.20 \\
3.50 \\
3.80\end{array}$ & $\begin{array}{l}3.23 \\
3.53 \\
3.83\end{array}$ & $\begin{array}{l}3.26 \\
3.56 \\
3.86\end{array}$ & $\begin{array}{l}3.29 \\
3.59 \\
3.89\end{array}$ & $\begin{array}{l}3.32 \\
3.62 \\
3.92\end{array}$ & $\begin{array}{l}3.35 \\
3.65 \\
3.95\end{array}$ & $\begin{array}{l}3.38 \\
3.68 \\
3.98\end{array}$ & $\begin{array}{l}3.41 \\
3.71 \\
4.01\end{array}$ & $\begin{array}{l}140 \\
150 \\
160\end{array}$ \\
\hline $\begin{array}{l}170 \\
180 \\
190\end{array}$ & $\begin{array}{l}4.01 \\
4.31 \\
4.61\end{array}$ & $\begin{array}{l}4.04 \\
4.34 \\
4.64\end{array}$ & $\begin{array}{l}4.07 \\
4.37 \\
4.67\end{array}$ & $\begin{array}{l}4.10 \\
4.40 \\
4.70\end{array}$ & $\begin{array}{l}4.13 \\
4.43 \\
4.73\end{array}$ & $\begin{array}{l}4.16 \\
4.46 \\
4.76\end{array}$ & $\begin{array}{l}4.19 \\
4.49 \\
4.79\end{array}$ & $\begin{array}{l}4.22 \\
4.52 \\
4.82\end{array}$ & $\begin{array}{l}4.25 \\
4.55 \\
4.85\end{array}$ & $\begin{array}{l}4.28 \\
4.58 \\
4.88\end{array}$ & $\begin{array}{l}4.31 \\
4.61 \\
4.91\end{array}$ & $\begin{array}{l}170 \\
180 \\
190\end{array}$ \\
\hline 200 & 4.91 & 4.94 & 4.97 & 5.00 & 5.03 & 5.06 & 5.09 & 5.12 & 5.15 & 5.18 & 5.21 & 200 \\
\hline $\begin{array}{l}210 \\
220 \\
230\end{array}$ & $\begin{array}{l}5.21 \\
5.51 \\
5.81\end{array}$ & $\begin{array}{l}5.24 \\
5.54 \\
5.84\end{array}$ & $\begin{array}{l}5.27 \\
5.57 \\
5.87\end{array}$ & $\begin{array}{l}5.30 \\
5.60 \\
5.90\end{array}$ & $\begin{array}{l}5.33 \\
5.63 \\
5.93\end{array}$ & $\begin{array}{l}5.36 \\
5.66 \\
5.96\end{array}$ & $\begin{array}{l}5.39 \\
5.69 \\
5.99\end{array}$ & $\begin{array}{l}5.42 \\
5.72 \\
6.02\end{array}$ & $\begin{array}{l}5.45 \\
5.75 \\
6.05\end{array}$ & $\begin{array}{l}5.48 \\
5.78 \\
6.08\end{array}$ & $\begin{array}{l}5.51 \\
5.81 \\
6.11\end{array}$ & $\begin{array}{l}210 \\
220 \\
230\end{array}$ \\
\hline $\begin{array}{l}240 \\
250 \\
260\end{array}$ & $\begin{array}{l}6.11 \\
6.42 \\
6.72\end{array}$ & $\begin{array}{l}6.14 \\
6.45 \\
6.75\end{array}$ & $\begin{array}{l}6.17 \\
6.48 \\
6.78\end{array}$ & $\begin{array}{l}6.20 \\
6.51 \\
6.81\end{array}$ & $\begin{array}{l}6.24 \\
6.54 \\
6.84\end{array}$ & $\begin{array}{l}6.27 \\
6.57 \\
6.87\end{array}$ & $\begin{array}{l}6.30 \\
6.60 \\
6.90\end{array}$ & $\begin{array}{l}6.33 \\
6.63 \\
6.93\end{array}$ & $\begin{array}{l}6.36 \\
6.66 \\
6.96\end{array}$ & $\begin{array}{l}6.39 \\
6.69 \\
7.00\end{array}$ & $\begin{array}{l}6.42 \\
6.72 \\
7.03\end{array}$ & $\begin{array}{l}240 \\
250 \\
260\end{array}$ \\
\hline $\begin{array}{l}270 \\
280 \\
290\end{array}$ & $\begin{array}{l}7.03 \\
7.33 \\
7.64\end{array}$ & $\begin{array}{l}7.06 \\
7.36 \\
7.67\end{array}$ & $\begin{array}{l}7.09 \\
7.39 \\
7.70\end{array}$ & $\begin{array}{l}7.12 \\
7.42 \\
7.73\end{array}$ & $\begin{array}{l}7.15 \\
7.45 \\
7.76\end{array}$ & $\begin{array}{l}7.18 \\
7.48 \\
7.79\end{array}$ & $\begin{array}{l}7.21 \\
7.51 \\
7.82\end{array}$ & $\begin{array}{l}7.24 \\
7.54 \\
7.85\end{array}$ & $\begin{array}{l}7.27 \\
7.58 \\
7.88\end{array}$ & $\begin{array}{l}7.30 \\
7.61 \\
7.91\end{array}$ & $\begin{array}{l}7.33 \\
7.64 \\
7.94\end{array}$ & $\begin{array}{l}270 \\
280 \\
290\end{array}$ \\
\hline 300 & 7.94 & 7.97 & 8.00 & 8.04 & 8.07 & 8.10 & 8.13 & 8.16 & 8.19 & 8.22 & 8.25 & 300 \\
\hline
\end{tabular}

*Based on the International Temperature Scale of 1948. 
Table 7. Iron-Constantan Thermocouples-Continued

(Emf in Absolute Millivolts. Temperatures in Degrees F. ${ }^{*}$ Reference Junctions at $32^{\circ} F_{.}$)

\begin{tabular}{|c|c|c|c|c|c|c|c|c|c|c|c|c|}
\hline${ }^{\circ} \mathrm{F}$ & 0 & 1 & 2 & 3 & 4 & 5 & 6 & 7 & 8 & 9 & 10 & \multirow{3}{*}{$\begin{array}{l}{ }^{\circ} \mathrm{F} \\
300\end{array}$} \\
\hline & \multicolumn{11}{|c|}{ Millivolts } & \\
\hline 300 & 7.94 & 7.97 & 8.00 & 8.04 & 8.07 & 8.10 & 8.13 & 8.16 & 8.19 & 8.22 & 8.25 & \\
\hline $\begin{array}{l}310 \\
320 \\
330\end{array}$ & $\begin{array}{l}8.25 \\
8.56 \\
8.87\end{array}$ & $\begin{array}{l}8.28 \\
8.59 \\
8.90\end{array}$ & $\begin{array}{l}8.31 \\
8.62 \\
8.93\end{array}$ & $\begin{array}{l}8.34 \\
8.65 \\
8.96\end{array}$ & $\begin{array}{l}8.37 \\
8.68 \\
8.99\end{array}$ & $\begin{array}{l}8.40 \\
8.71 \\
9.02\end{array}$ & $\begin{array}{l}8.44 \\
8.74 \\
9.05\end{array}$ & $\begin{array}{l}8.47 \\
8.77 \\
9.08\end{array}$ & $\begin{array}{l}8.50 \\
8.80 \\
9.11\end{array}$ & $\begin{array}{l}8.53 \\
8.84 \\
9.14\end{array}$ & $\begin{array}{l}8.56 \\
8.87 \\
9.17\end{array}$ & $\begin{array}{l}310 \\
320 \\
330\end{array}$ \\
\hline $\begin{array}{l}340 \\
350 \\
360\end{array}$ & $\begin{array}{l}9.17 \\
9.48 \\
9.79\end{array}$ & $\begin{array}{l}9.20 \\
9.51 \\
9.82\end{array}$ & $\begin{array}{l}9.24 \\
9.54 \\
9.85\end{array}$ & $\begin{array}{l}9.27 \\
9.58 \\
9.88\end{array}$ & $\begin{array}{l}9.30 \\
9.61 \\
9.92\end{array}$ & $\begin{array}{l}9.33 \\
9.64 \\
9.95\end{array}$ & $\begin{array}{l}9.36 \\
9.67 \\
9.98\end{array}$ & $\begin{array}{r}9.39 \\
9.70 \\
10.01\end{array}$ & $\begin{array}{r}9.42 \\
9.73 \\
10.04\end{array}$ & $\begin{array}{r}9.45 \\
9.76 \\
10.07\end{array}$ & $\begin{array}{r}9.48 \\
9.79 \\
10.10\end{array}$ & $\begin{array}{l}340 \\
350 \\
360\end{array}$ \\
\hline $\begin{array}{l}370 \\
380 \\
390\end{array}$ & $\begin{array}{l}10.10 \\
10.41 \\
10.72\end{array}$ & $\begin{array}{l}10.13 \\
10.44 \\
10.75\end{array}$ & $\begin{array}{l}10.16 \\
10.47 \\
10.78\end{array}$ & $\begin{array}{l}10.19 \\
10.50 \\
10.81\end{array}$ & $\begin{array}{l}10.22 \\
10.53 \\
10.84\end{array}$ & $\begin{array}{l}10.25 \\
10.56 \\
10.87\end{array}$ & $\begin{array}{l}10.28 \\
10.60 \\
10.90\end{array}$ & $\begin{array}{l}10.32 \\
10.63 \\
10.94\end{array}$ & $\begin{array}{l}10.35 \\
10.66 \\
10.97\end{array}$ & $\begin{array}{l}10.38 \\
10.69 \\
11.00\end{array}$ & $\begin{array}{l}10.41 \\
10.72 \\
11.03\end{array}$ & $\begin{array}{l}370 \\
380 \\
390\end{array}$ \\
\hline 400 & 11.03 & 11.06 & 11.09 & 11.12 & 11.15 & 11.18 & 11.21 & 11.24 & 11.28 & 11.31 & 11.34 & 400 \\
\hline $\begin{array}{l}410 \\
420 \\
430\end{array}$ & $\begin{array}{l}11.34 \\
11.65 \\
11.96\end{array}$ & $\begin{array}{l}11.37 \\
11.68 \\
11.99\end{array}$ & $\begin{array}{l}11.40 \\
11.71 \\
12.02\end{array}$ & $\begin{array}{l}11.43 \\
11.74 \\
12.05\end{array}$ & $\begin{array}{l}11.46 \\
11.77 \\
12.08\end{array}$ & $\begin{array}{l}11.49 \\
11.80 \\
12.11\end{array}$ & $\begin{array}{l}11.52 \\
11.83 \\
12.14\end{array}$ & $\begin{array}{l}11.55 \\
11.86 \\
12.17\end{array}$ & $\begin{array}{l}11.58 \\
11.89 \\
12.20\end{array}$ & $\begin{array}{l}11.62 \\
11.92 \\
12.23\end{array}$ & $\begin{array}{l}11.65 \\
11.96 \\
12.26\end{array}$ & $\begin{array}{l}410 \\
420 \\
430\end{array}$ \\
\hline $\begin{array}{l}440 \\
450 \\
460\end{array}$ & $\begin{array}{l}12.26 \\
12.57 \\
12.88\end{array}$ & $\begin{array}{l}12.30 \\
12.60 \\
12.91\end{array}$ & $\begin{array}{l}12.33 \\
12.64 \\
12.94\end{array}$ & $\begin{array}{l}12.36 \\
12.67 \\
12.98\end{array}$ & $\begin{array}{l}12.39 \\
12.70 \\
13.01\end{array}$ & $\begin{array}{l}12.42 \\
12.73 \\
13.04\end{array}$ & $\begin{array}{l}12.45 \\
12.76 \\
13.07\end{array}$ & $\begin{array}{l}12.48 \\
12.79 \\
13.10\end{array}$ & $\begin{array}{l}12.51 \\
12.82 \\
13.13\end{array}$ & $\begin{array}{l}12.54 \\
12.85 \\
13.16\end{array}$ & $\begin{array}{l}12.57 \\
12.88 \\
13.19\end{array}$ & $\begin{array}{l}440 \\
450 \\
460\end{array}$ \\
\hline $\begin{array}{l}470 \\
480 \\
490\end{array}$ & $\begin{array}{l}13.19 \\
13.50 \\
13.81\end{array}$ & $\begin{array}{l}13.22 \\
13.53 \\
13.84\end{array}$ & $\begin{array}{l}13.25 \\
13.56 \\
13.87\end{array}$ & $\begin{array}{l}13.28 \\
13.59 \\
13.90\end{array}$ & $\begin{array}{l}13.31 \\
13.62 \\
13.93\end{array}$ & $\begin{array}{l}13.34 \\
13.65 \\
13.96\end{array}$ & $\begin{array}{l}13.38 \\
13.68 \\
13.99\end{array}$ & $\begin{array}{l}13.41 \\
13.72 \\
14.02\end{array}$ & $\begin{array}{l}13.44 \\
13.75 \\
14.05\end{array}$ & $\begin{array}{l}13.47 \\
13.78 \\
14.08\end{array}$ & $\begin{array}{l}13.50 \\
13.81 \\
14.12\end{array}$ & $\begin{array}{l}470 \\
480 \\
490\end{array}$ \\
\hline 500 & 14.12 & 14.15 & 14.18 & 14.21 & 14.24 & 14.27 & 14.30 & 14.33 & 14.36 & 14.39 & 14.42 & 500 \\
\hline $\begin{array}{l}510 \\
520 \\
530\end{array}$ & $\begin{array}{l}14.42 \\
14.73 \\
15.04\end{array}$ & $\begin{array}{l}14.45 \\
14.76 \\
15.07\end{array}$ & $\begin{array}{l}14.48 \\
14.79 \\
15.10\end{array}$ & $\begin{array}{l}14.52 \\
14.82 \\
15.13\end{array}$ & $\begin{array}{l}14.55 \\
14.85 \\
15.16\end{array}$ & $\begin{array}{l}14.58 \\
14.88 \\
15.19\end{array}$ & $\begin{array}{l}14.61 \\
14.91 \\
15.22\end{array}$ & $\begin{array}{l}14.64 \\
14.94 \\
15.25\end{array}$ & $\begin{array}{l}14.67 \\
14.98 \\
15.28\end{array}$ & & $\begin{array}{l}14.73 \\
15.04 \\
15.34\end{array}$ & $\begin{array}{l}510 \\
520 \\
530\end{array}$ \\
\hline $\begin{array}{l}540 \\
550 \\
560\end{array}$ & $\begin{array}{l}15.34 \\
15.65 \\
15.96\end{array}$ & $\begin{array}{l}15.37 \\
15.68 \\
15.99\end{array}$ & $\begin{array}{l}15.40 \\
15.71 \\
16.02\end{array}$ & $\begin{array}{l}15.44 \\
15.74 \\
16.05\end{array}$ & $\begin{array}{l}15.47 \\
15.77 \\
16.08\end{array}$ & $\begin{array}{l}15.50 \\
15.80 \\
16.11\end{array}$ & $\begin{array}{l}15.53 \\
15.84 \\
16.14\end{array}$ & $\begin{array}{l}15.56 \\
15.87 \\
16.17\end{array}$ & $\begin{array}{l}15.59 \\
15.90 \\
16.20\end{array}$ & $\begin{array}{l}15.62 \\
15.93 \\
16.23\end{array}$ & $\begin{array}{l}15.65 \\
15.96 \\
16.26\end{array}$ & $\begin{array}{l}540 \\
550 \\
560\end{array}$ \\
\hline $\begin{array}{l}570 \\
580 \\
590\end{array}$ & $\begin{array}{l}16.26 \\
16.57 \\
16.88\end{array}$ & $\begin{array}{l}16.30 \\
16.60 \\
16.91\end{array}$ & $\begin{array}{l}16.33 \\
16.63 \\
16.94\end{array}$ & $\begin{array}{l}16.36 \\
16.66 \\
16.97\end{array}$ & $\begin{array}{l}16.39 \\
16.69 \\
17.00\end{array}$ & $\begin{array}{l}16.42 \\
16.72 \\
17.03\end{array}$ & $\begin{array}{l}16.45 \\
16.75 \\
17.06\end{array}$ & $\begin{array}{l}16.48 \\
16.78 \\
17.09\end{array}$ & $\begin{array}{l}16.51 \\
16.82 \\
17.12\end{array}$ & $\begin{array}{l}16.54 \\
16.85 \\
17.15\end{array}$ & $\begin{array}{l}16.57 \\
16.88 \\
17.18\end{array}$ & $\begin{array}{l}570 \\
580 \\
590\end{array}$ \\
\hline 600 & 17.18 & 17.21 & 17.24 & 17.28 & 17.31 & 17.34 & 17.37 & 17.40 & 17.43 & 17.46 & 17.49 & 600 \\
\hline
\end{tabular}

* Based on the International Temperature Scale of 1948. 
Table 7. Iron-Constantan Thermocouples-Continued

(Fmf in Absolute Millivolts. Temperatures in Degrees F. Reference Junctions at $32^{\circ} F_{\text {. }}$ )

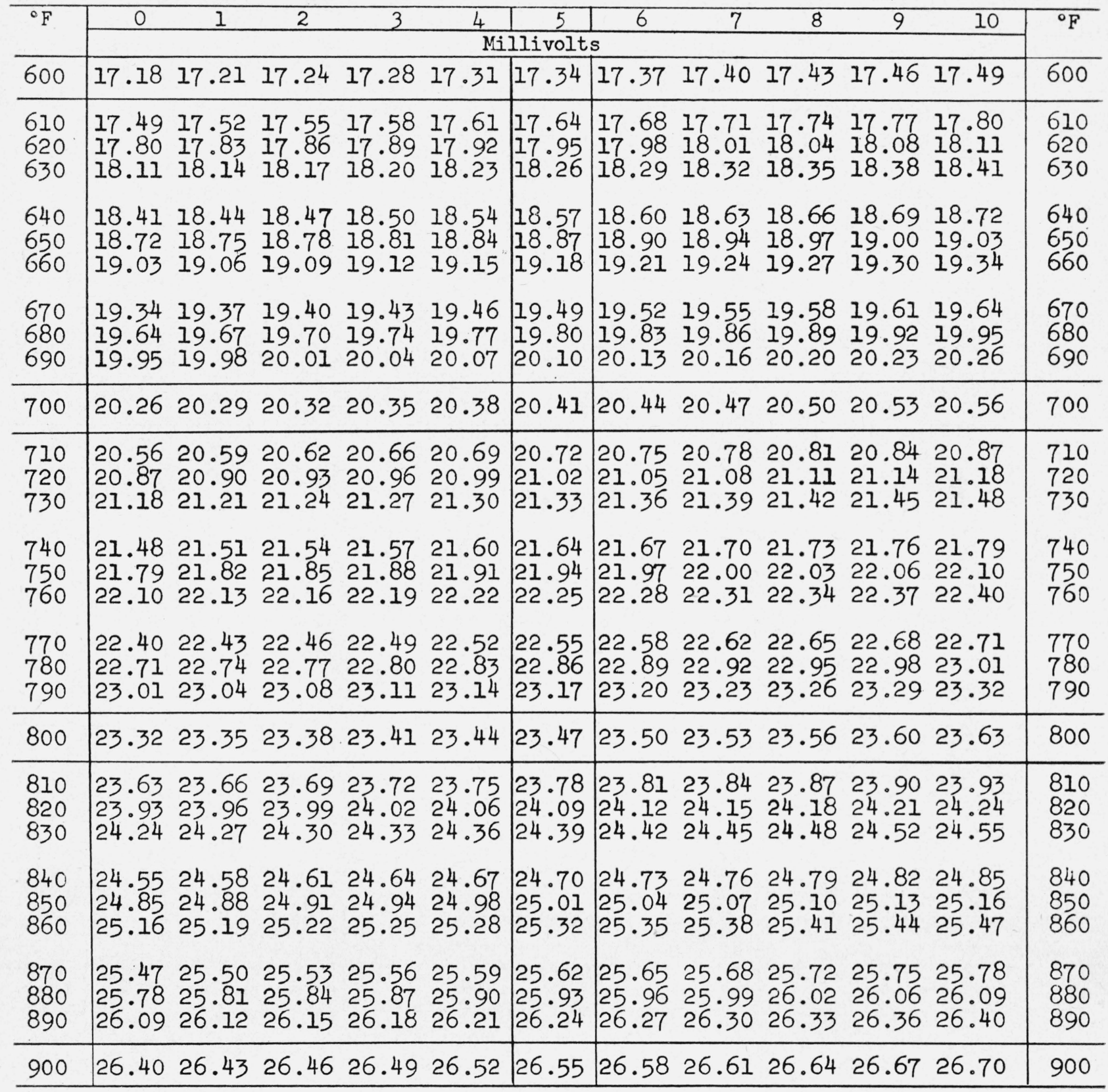

* Based on the International Temperature Scale of 1948. 
Table 7. Iron-Constantan Thermocouples-Continued

(Emf in Absolute Millivolts Temperatures in Degrees F. ${ }^{*}$ Reference Junctions at $32^{\circ}$ F.)

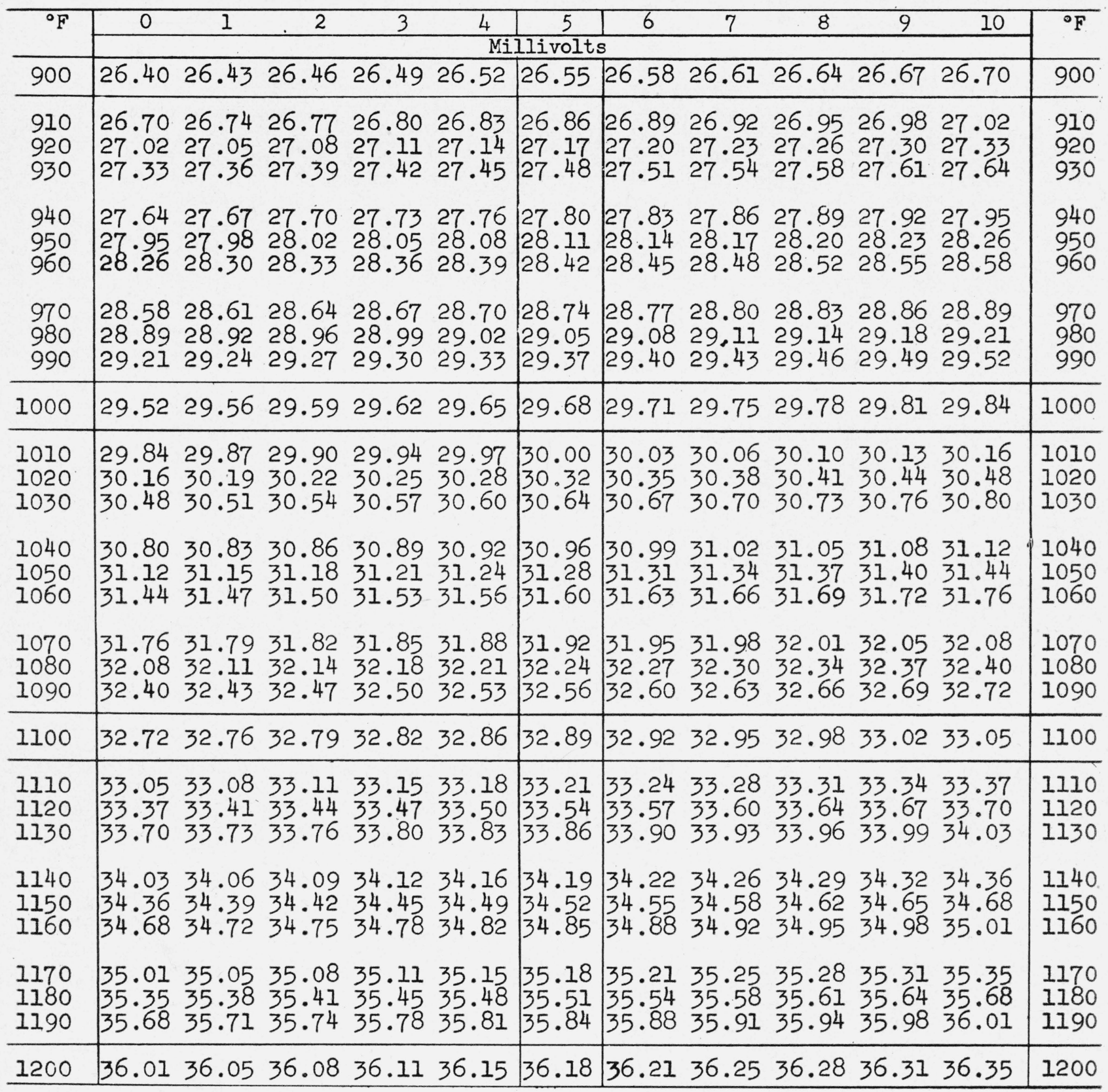

*Based on the International Temperature Scale of 1948. 
Table 7. Iron-Constantan Thernocouples-Continued

(Emf in Absolute Millivolts. Temperatures in Degrees F. ${ }^{*}$ Reference Junctions at $32^{\circ} F_{\text {. }}$ )

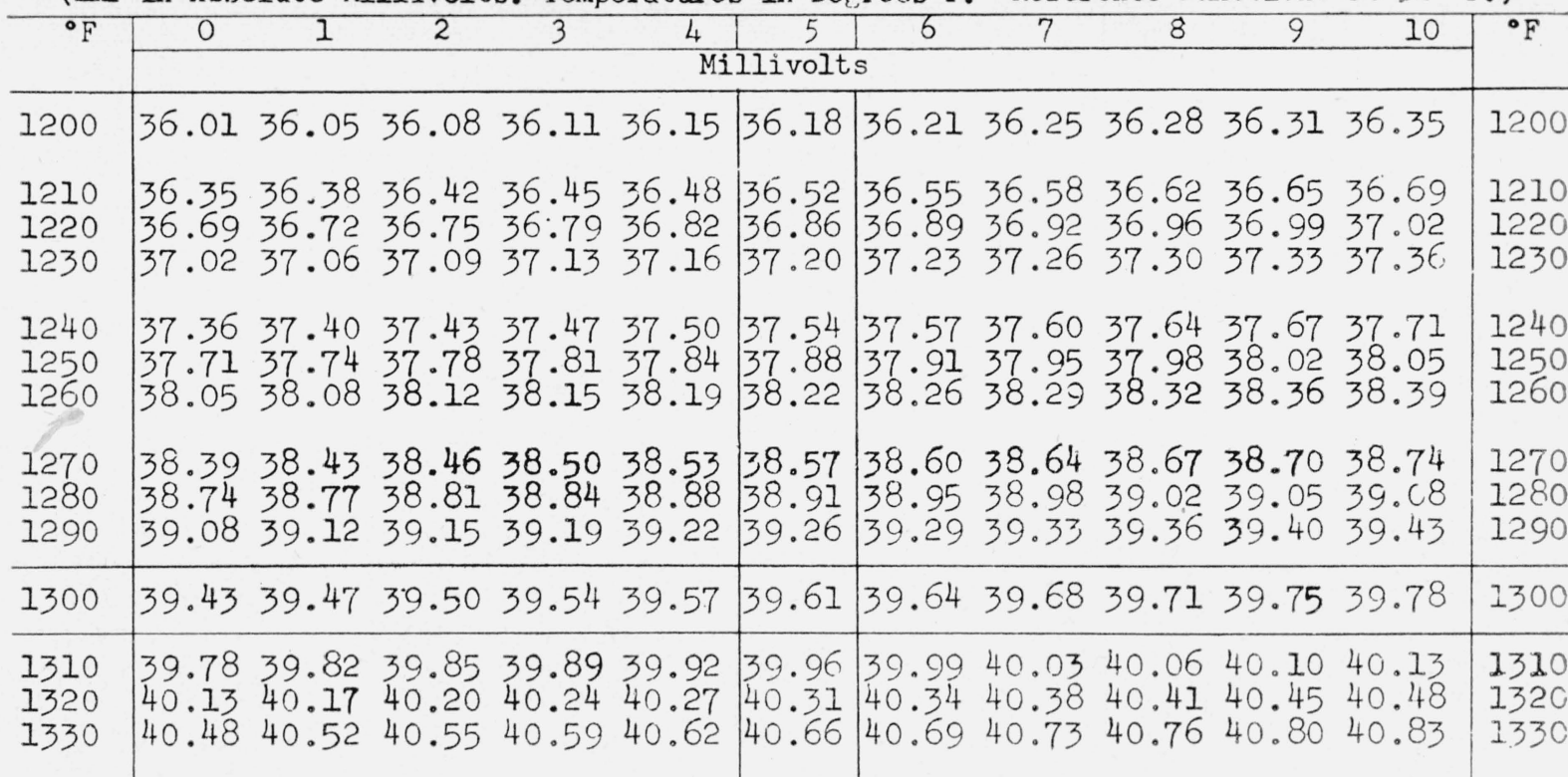

$1340 \quad 40.83 \quad 40.87 \quad 40.90 \quad 40.94 \quad 40.98 \quad 41.01 \quad 41.05 \quad 41.08 \quad 41.12 \quad 41.15 \quad 41.19 \quad 131+0$

$1350 \quad 41.1941 .22 \quad 41.2641 .2941 .33 \quad 41.36 \quad 41.40 \quad 41.43 \quad 41.47 \quad 41.50 \quad 41.54 \quad 1350$

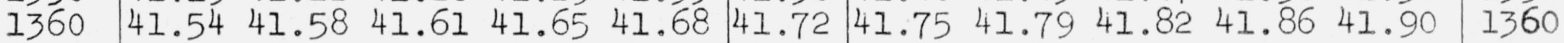

$\begin{array}{llllllllllllllll}1370 & 41.90 & 41.93 & 41.97 & 42.00 & 42.04 & 42.07 & 42.11 & 42.14 & 42.18 & 42.22 & 42.25 & 1370\end{array}$

$1380 \quad 42.25 \quad 42.2942 .32 \quad 42.3642 .39 \quad 42.43 \quad 42.46 \quad 42.5042 .53 \quad 42.57 \quad 42.61 \quad 1380$

$\begin{array}{lllllllllllll}1390 & 42.61 & 42.64 & 42.68 & 42.71 & 42.75 & 42.78 & 42.82 & 42.85 & 42.89 & 42.92 & 42.96 & 1390\end{array}$

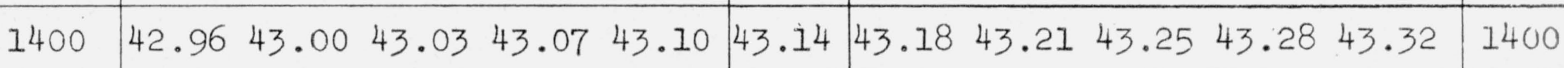

$\begin{array}{llllllllllllllllll}1410 & 43.32 & 43.35 & 43.39 & 43.43 & 43.46 & 43.50 & 43.53 & 43.57 & 43.60 & 43.64 & 43.68 & 1410\end{array}$

$1420 \quad 43.68 \quad 43.71 \quad 43.75 \quad 43.78 \quad 43.82 \quad 43.85 \quad 43.8943 .92 \quad 43.96 \quad 44.00 \quad 44.03 \quad 1420$

$1430 \quad 44.03 \quad 44.07 \quad 44.10 \quad 44.14 \quad 44.18 \quad 44.21 \quad 44.25 \quad 44.28 \quad 44.32 \quad 44.35 \quad 44.39 \quad 1430$

$\begin{array}{lllllllllllllllll}1440 & 44.39 & 44.42 & 44.46 & 44.50 & 44.53 & 44.57 & 44.60 & 44.64 & 44.68 & 44.71 & 44.75 & 1440\end{array}$

$\begin{array}{llllllllllllllllll}1450 & 44.75 & 44.78 & 44.82 & 44.85 & 44.89 & 44.93 & 44.96 & 45.00 & 45.03 & 45.07 & 45.10 & 1450\end{array}$

$1460 \quad 45.10 \quad 45.14 \quad 45.18 \quad 45.21 \quad 45.25 \quad 45.28 \quad 45.32 \quad 45.35 \quad 45.3945 .42 \quad 45.46 \quad 1460$

$1470 \quad 45.46 \quad 45.50 \quad 45.53 \quad 45.57 \quad 45.60 \quad 45.64 \quad 45.68 \quad 45.71 \quad 45.75 \quad 45.78 \quad 45.82 \quad 1470$

$\begin{array}{lllllllllllllll}1480 & 45.82 & 45.85 & 45.89 & 45.92 & 45.96 & 46.00 & 46.03 & 46.07 & 46.10 & 46.14 & 46.18 & 1480\end{array}$

$\begin{array}{lllllllllllll}1490 & 46.18 & 46.21 & 46.25 & 46.28 & 46.32 & 46.35 & 46.39 & 46.42 & 46.46 & 46.50 & 46.53 & 1490\end{array}$

\begin{tabular}{l|lllllllllllllll}
\hline 1500 & 46.53 & 46.57 & 46.60 & 46.64 & 46.67 & 46.71 & 46.74 & 46.78 & 46.82 & 46.85 & 46.89 & 1500
\end{tabular}

\begin{tabular}{l|llllll|llllllllll}
1510 & 46.89 & 46.92 & 46.96 & 47.00 & 47.03 & 47.07 & 47.10 & 47.14 & 47.17 & 47.21 & 47.24 & 1510
\end{tabular}

$1520 \quad 47.24 \quad 47.28 \quad 47.32 \quad 47.35 \quad 47.3947 .42 \quad 47.46 \quad 47.4947 .5347 .56 \quad 47.60 \quad 1520$

$1530 \quad 47.60 \quad 47.6347 .67 \quad 47.70 \quad 47.74 \quad 47.78 \quad 47.81 \quad 47.85 \quad 47.8847 .92 \quad 47.95 \quad 1530$

$1540 \quad 47.95 \quad 47.9948 .02 \quad 48.0648 .09 \quad 48.13 \quad 48.16 \quad 48.20 \quad 48.24 \quad 48.27 \quad 48.31 \quad 1540$

$1550 \quad 48.31 \quad 48.34 \quad 48.38 \quad 48.41 \quad 48.45 \quad 48.48 \quad 48.52 \quad 48.55 \quad 48.5948 .62 \quad 48.66 \quad 1550$

$1560 \quad 48.66 \quad 48.6948 .73 \quad 48.76 \quad 48.80 \quad 48.83 \quad 48.87 \quad 48.90 \quad 48.94 \quad 48.97 \quad 49.011 \quad 1560$

$\begin{array}{lllllllllllll}1570 & 49.01 & 49.04 & 49.08 & 49.11 & 49.15 & 49.18 & 49.22 & 49.25 & 49.29 & 49.32 & 49.36 & 1570\end{array}$ $1580 \quad 49.36 \quad 49.3949 .43 \quad 49.46 \quad 49.50 \quad 49.53 \quad 49.56 \quad 49.60 \quad 49.6349 .67 \quad 49.70 \quad 1580$ $1590 \quad 49.70 \quad 49.74 \quad 49.77 \quad 49.81 \quad 49.84 \quad 49.88 \quad 49.91 \quad 49.94 \quad 49.9850 .0150 .05 \quad 1590$

\begin{tabular}{l|l|l|l|l}
\hline 1600 & 50.05 & & & .1600 \\
\hline
\end{tabular}

*Based on the International Temperature Scale of 1948 . 
Table 8. Iron-Constantan Thermocouples

(Emf in Absolute Millivolts. Temperatures in Degrees $F^{*}$. Reference Junctions at $32^{\circ} \mathrm{F}$ )

\begin{tabular}{|c|c|c|c|c|c|c|c|c|c|c|c|c|}
\hline \multirow[t]{2}{*}{ Millivolts } & .00 & .10 & .20 & .30 & .40 & .50 & .60 & .70 & .80 & .90 & 1.00 & \multirow[t]{2}{*}{ Millivolts } \\
\hline & \multicolumn{11}{|c|}{ Degrees F } & \\
\hline-7.00 & -267 & -273 & -279 & -285 & -292 & -298 & -305 & -313 & -320 & & & -7.00 \\
\hline $\begin{array}{l}-6.00 \\
-5.00 \\
-4.00\end{array}$ & $\begin{array}{l}-212 \\
-165 \\
-121\end{array}$ & $\begin{array}{l}-217 \\
-169 \\
-125\end{array}$ & $\begin{array}{l}-222 \\
-174 \\
-13.0\end{array}$ & $\begin{array}{l}-228 \\
-178 \\
-134\end{array}$ & $\begin{array}{l}-233 \\
-183 \\
-138\end{array}$ & $\begin{array}{l}-238 \\
-188 \\
-142\end{array}$ & $\begin{array}{l}-244 \\
-192 \\
-147\end{array}$ & $\begin{array}{l}-249 \\
-197 \\
-151\end{array}$ & $\begin{array}{l}-255 \\
-202 \\
-156\end{array}$ & $\begin{array}{l}-261 \\
-207 \\
-160\end{array}$ & $\begin{array}{l}-267 \\
-212 \\
-165\end{array}$ & $\begin{array}{l}-6.00 \\
-5.00 \\
-4.00\end{array}$ \\
\hline $\begin{array}{l}-3.00 \\
-2.00 \\
-1.00\end{array}$ & $\begin{array}{r}-80 \\
-42 \\
-4\end{array}$ & $\begin{array}{r}-84 \\
-45 \\
-8\end{array}$ & $\begin{array}{l}-88 \\
-49 \\
-12\end{array}$ & $\begin{array}{l}-92 \\
-53 \\
-15\end{array}$ & $\begin{array}{l}-96 \\
-57 \\
-19\end{array}$ & $\begin{array}{l}-100 \\
-61 \\
-23\end{array}$ & $\begin{array}{l}-105 \\
-65 \\
-26\end{array}$ & $\begin{array}{r}-109 \\
-69 \\
-30\end{array}$ & $\begin{array}{r}-113 \\
-72 \\
-34\end{array}$ & $\begin{array}{r}-117 \\
-76 \\
-38\end{array}$ & $\begin{array}{r}-121 \\
-80 \\
-42\end{array}$ & $\begin{array}{l}-3.00 \\
-2.00 \\
-1.00\end{array}$ \\
\hline$(-) 0.00$ & 32 & 29 & 25 & 21 & 18 & 14 & 10 & 7 & 3 & 0 & -4 & $(-) 0.00$ \\
\hline$(+) 0.00$ & 32 & 36 & 39 & 43 & 46 & 50 & 53 & 57 & 60 & 64 & 67 & $(t) 0.00$ \\
\hline $\begin{array}{l}1.00 \\
2.00 \\
3.00\end{array}$ & $\begin{array}{r}67 \\
102 \\
136\end{array}$ & $\begin{array}{l}71 \\
105 \\
140\end{array}$ & $\begin{array}{r}74 \\
109 \\
143\end{array}$ & $\begin{array}{r}78 \\
112 \\
146\end{array}$ & $\begin{array}{r}81 \\
116 \\
150\end{array}$ & $\begin{array}{r}85 \\
119 \\
153\end{array}$ & $\begin{array}{r}88 \\
123 \\
156\end{array}$ & $\begin{array}{r}92 \\
126 \\
160\end{array}$ & $\begin{array}{r}95 \\
129 \\
163\end{array}$ & $\begin{array}{r}99 \\
133 \\
166\end{array}$ & $\begin{array}{l}102 \\
136 \\
170\end{array}$ & $\begin{array}{l}1.00 \\
2.00 \\
3.00\end{array}$ \\
\hline $\begin{array}{l}4.00 \\
5.00 \\
6.00\end{array}$ & $\begin{array}{l}170 \\
203 \\
236\end{array}$ & $\begin{array}{l}173 \\
206 \\
240\end{array}$ & $\begin{array}{l}177 \\
210 \\
243\end{array}$ & $\begin{array}{l}180 \\
213 \\
246\end{array}$ & $\begin{array}{l}183 \\
216 \\
249\end{array}$ & $\begin{array}{l}187 \\
220 \\
253\end{array}$ & $\begin{array}{l}190 \\
223 \\
256\end{array}$ & $\begin{array}{l}193 \\
226 \\
259\end{array}$ & $\begin{array}{l}196 \\
230 \\
263\end{array}$ & $\begin{array}{l}200 \\
233 \\
266\end{array}$ & $\begin{array}{l}203 \\
236 \\
269\end{array}$ & $\begin{array}{l}4.00 \\
5.00 \\
6.00\end{array}$ \\
\hline $\begin{array}{l}7.00 \\
8.00 \\
9.00\end{array}$ & $\begin{array}{l}269 \\
302 \\
334\end{array}$ & $\begin{array}{l}272 \\
305 \\
338\end{array}$ & $\begin{array}{l}276 \\
308 \\
341\end{array}$ & $\begin{array}{l}279 \\
312 \\
344\end{array}$ & $\begin{array}{l}282 \\
315 \\
347\end{array}$ & $\begin{array}{l}286 \\
318 \\
351\end{array}$ & $\begin{array}{l}289 \\
321 \\
354\end{array}$ & $\begin{array}{l}292 \\
325 \\
357\end{array}$ & $\begin{array}{l}295 \\
328 \\
360\end{array}$ & $\begin{array}{l}299 \\
331 \\
364\end{array}$ & $\begin{array}{l}302 \\
334 \\
367\end{array}$ & $\begin{array}{l}7.00 \\
8.00 \\
9.00\end{array}$ \\
\hline 10.00 & 367 & 370 & 373 & 376 & 380 & 383 & 386 & 389 & 393 & 396 & 399 & 10.00 \\
\hline $\begin{array}{l}11.00 \\
12.00 \\
13.00\end{array}$ & $\begin{array}{l}399 \\
431 \\
464\end{array}$ & $\begin{array}{l}402 \\
435 \\
467\end{array}$ & $\begin{array}{l}406 \\
438 \\
470\end{array}$ & $\begin{array}{l}409 \\
441 \\
474\end{array}$ & $\begin{array}{l}412 \\
444 \\
477\end{array}$ & $\begin{array}{l}415 \\
448 \\
480\end{array}$ & $\begin{array}{l}419 \\
451 \\
483\end{array}$ & $\begin{array}{l}422 \\
454 \\
487\end{array}$ & $\begin{array}{l}425 \\
457 \\
490\end{array}$ & $\begin{array}{l}428 \\
461 \\
493\end{array}$ & $\begin{array}{l}431 \\
464 \\
496\end{array}$ & $\begin{array}{l}11.00 \\
12.00 \\
13.00\end{array}$ \\
\hline $\begin{array}{l}14.00 \\
15.00 \\
16.00\end{array}$ & $\begin{array}{l}496 \\
529 \\
561\end{array}$ & $\begin{array}{l}499 \\
532 \\
565\end{array}$ & $\begin{array}{l}503 \\
535 \\
568\end{array}$ & $\begin{array}{l}506 \\
539 \\
571\end{array}$ & $\begin{array}{l}509 \\
542 \\
574\end{array}$ & $\begin{array}{l}513 \\
545 \\
578\end{array}$ & $\begin{array}{l}516 \\
548 \\
581\end{array}$ & $\begin{array}{l}519 \\
552 \\
584\end{array}$ & $\begin{array}{l}522 \\
555 \\
587\end{array}$ & $\begin{array}{l}526 \\
558 \\
591\end{array}$ & $\begin{array}{l}529 \\
561 \\
594\end{array}$ & $\begin{array}{l}14.00 \\
15.00 \\
16.00\end{array}$ \\
\hline $\begin{array}{l}17.00 \\
18.00 \\
19.00\end{array}$ & $\begin{array}{l}594 \\
627 \\
659\end{array}$ & $\begin{array}{l}597 \\
630 \\
662\end{array}$ & $\begin{array}{l}601 \\
633 \\
666\end{array}$ & $\begin{array}{l}604 \\
636 \\
669\end{array}$ & $\begin{array}{l}607 \\
640 \\
672\end{array}$ & $\begin{array}{l}610 \\
643 \\
675\end{array}$ & $\begin{array}{l}614 \\
646 \\
679\end{array}$ & $\begin{array}{l}617 \\
649 \\
682\end{array}$ & $\begin{array}{l}620 \\
653 \\
685\end{array}$ & $\begin{array}{l}623 \\
656 \\
688\end{array}$ & $\begin{array}{l}627 \\
659 \\
692\end{array}$ & $\begin{array}{l}17.00 \\
18.00 \\
19.00\end{array}$ \\
\hline 20.00 & 692 & 695 & 698 & 701 & 705 & 708 & 711 & 714 & 718 & 721 & 724 & 20.00 \\
\hline
\end{tabular}

*Based on the International Temperature Scale of 1948. 
Table 8. Iron-Constantan Thermocouples-Continued

(Emf in Absolute Millivolts. Temperatures in Degrees $F^{*}$. Reference Junctions at $32^{\circ} \mathrm{F}$ )

\begin{tabular}{|c|c|c|c|c|c|c|c|c|c|c|c|c|}
\hline \multirow[t]{2}{*}{ Millivolts } & .00 & .10 & .20 & .30 & .40 & .50 & .60 & .70 & .80 & .90 & 1.00 & \multirow[t]{2}{*}{ Millivolts } \\
\hline & \multicolumn{11}{|c|}{ Degrees F } & \\
\hline 20.00 & 692 & 695 & 698 & 701 & 705 & 708 & 711 & 714 & 718 & 721 & 724 & 20.00 \\
\hline $\begin{array}{l}21.00 \\
22.00 \\
23.00\end{array}$ & $\begin{array}{l}724 \\
757 \\
790\end{array}$ & $\begin{array}{l}727 \\
760 \\
793\end{array}$ & $\begin{array}{l}731 \\
763 \\
796\end{array}$ & $\begin{array}{l}734 \\
767 \\
799\end{array}$ & $\begin{array}{l}737 \\
770 \\
803\end{array}$ & $\begin{array}{l}741 \\
773 \\
806\end{array}$ & $\begin{array}{l}744 \\
777 \\
809\end{array}$ & $\begin{array}{l}747 \\
780 \\
812\end{array}$ & $\begin{array}{l}750 \\
783 \\
816\end{array}$ & $\begin{array}{l}754 \\
786 \\
819\end{array}$ & $\begin{array}{l}757 \\
790 \\
822\end{array}$ & $\begin{array}{l}21.00 \\
22.00 \\
23.00\end{array}$ \\
\hline $\begin{array}{l}24.00 \\
25.00 \\
26.00\end{array}$ & $\begin{array}{l}822 \\
855 \\
887\end{array}$ & $\begin{array}{l}825 \\
858 \\
890\end{array}$ & $\begin{array}{l}829 \\
861 \\
894\end{array}$ & $\begin{array}{l}832 \\
865 \\
897\end{array}$ & $\begin{array}{l}835 \\
868 \\
900\end{array}$ & $\begin{array}{l}839 \\
871 \\
903\end{array}$ & $\begin{array}{l}842 \\
874 \\
907\end{array}$ & $\begin{array}{l}845 \\
878 \\
910\end{array}$ & $\begin{array}{l}848 \\
881 \\
913\end{array}$ & $\begin{array}{l}852 \\
884 \\
916\end{array}$ & $\begin{array}{l}855 \\
887 \\
919\end{array}$ & $\begin{array}{l}24.00 \\
25.00 \\
26.00\end{array}$ \\
\hline $\begin{array}{l}27.00 \\
28.00 \\
29.00\end{array}$ & $\begin{array}{l}919 \\
952 \\
983\end{array}$ & $\begin{array}{l}923 \\
955 \\
987\end{array}$ & $\begin{array}{l}926 \\
958 \\
990\end{array}$ & $\begin{array}{l}929 \\
961 \\
993\end{array}$ & $\begin{array}{l}932 \\
964 \\
996\end{array}$ & $\begin{array}{l}936 \\
967 \\
999\end{array}$ & $\begin{array}{r}939 \\
971 \\
1002\end{array}$ & $\begin{array}{r}942 \\
974 \\
1006\end{array}$ & $\begin{array}{r}945 \\
977 \\
1009\end{array}$ & $\begin{array}{r}948 \\
980 \\
1012\end{array}$ & $\begin{array}{r}952 \\
983 \\
1015\end{array}$ & $\begin{array}{l}27.00 \\
28.00 \\
29.00\end{array}$ \\
\hline 30.00 & 1015 & 1018 & 1021 & 1024 & 1028 & 1031 & 1034 & 1037 & 1040 & 1043 & 1046 & 30.00 \\
\hline $\begin{array}{l}31.00 \\
32.00 \\
33.00\end{array}$ & $\begin{array}{l}1046 \\
1078 \\
1108\end{array}$ & $\begin{array}{l}1050 \\
1081 \\
1112\end{array}$ & $\begin{array}{l}1053 \\
1084 \\
1115\end{array}$ & $\begin{array}{l}1056 \\
1087 \\
1118\end{array}$ & $\begin{array}{l}1059 \\
1090 \\
1121\end{array}$ & $\begin{array}{l}1062 \\
1093 \\
1124\end{array}$ & $\begin{array}{l}1065 \\
1096 \\
1127\end{array}$ & $\begin{array}{l}1068 \\
1099 \\
1130\end{array}$ & $\begin{array}{l}1071 \\
1102 \\
1133\end{array}$ & $\begin{array}{l}1074 \\
1105 \\
1136\end{array}$ & $\begin{array}{l}1078 \\
1108 \\
1139\end{array}$ & $\begin{array}{l}31.00 \\
32.00 \\
33.00\end{array}$ \\
\hline $\begin{array}{l}34.00 \\
35.00 \\
36.00\end{array}$ & $\begin{array}{l}1139 \\
1170 \\
1200\end{array}$ & $\begin{array}{l}1142 \\
1173 \\
1203\end{array}$ & $\begin{array}{l}1145 \\
1176 \\
1206\end{array}$ & $\begin{array}{l}1148 \\
1179 \\
1209\end{array}$ & $\begin{array}{l}1151 \\
1182 \\
1212\end{array}$ & $\begin{array}{l}1154 \\
1185 \\
1215\end{array}$ & $\begin{array}{l}1157 \\
1188 \\
1217\end{array}$ & $\begin{array}{l}1160 \\
1191 \\
1220\end{array}$ & $\begin{array}{l}1164 \\
1194 \\
1223\end{array}$ & $\begin{array}{l}1167 \\
1197 \\
1226\end{array}$ & $\begin{array}{l}1170 \\
1200 \\
1229\end{array}$ & $\begin{array}{l}34.00 \\
35.00 \\
36.00\end{array}$ \\
\hline $\begin{array}{l}37.00 \\
38.00 \\
39.00\end{array}$ & $\begin{array}{l}1229 \\
1259 \\
1288\end{array}$ & $\begin{array}{l}1232 \\
1261 \\
1290\end{array}$ & $\begin{array}{l}1235 \\
1264 \\
1293\end{array}$ & $\begin{array}{l}1238 \\
1267 \\
1296\end{array}$ & $\begin{array}{l}1241 \\
1270 \\
1299\end{array}$ & $\begin{array}{l}1244 \\
1273 \\
1302\end{array}$ & $\begin{array}{l}1247 \\
1276 \\
1305\end{array}$ & $\begin{array}{l}1250 \\
1279 \\
1308\end{array}$ & $\begin{array}{l}1253 \\
1282 \\
1311\end{array}$ & $\begin{array}{l}1256 \\
1285 \\
1313\end{array}$ & $\begin{array}{l}1259 \\
1288 \\
1316\end{array}$ & $\begin{array}{l}37.00 \\
38.00 \\
39.00\end{array}$ \\
\hline 40.00 & 1316 & 1319 & 1322 & 1325 & 1328 & 1331 & 1333 & 1336 & 1339 & 1342 & 1345 & 40.00 \\
\hline $\begin{array}{l}41.00 \\
42.00 \\
43.00\end{array}$ & $\begin{array}{l}1345 \\
1373 \\
1401\end{array}$ & $\begin{array}{l}1348 \\
1376 \\
1404\end{array}$ & $\begin{array}{l}1350 \\
1379 \\
1407\end{array}$ & $\begin{array}{l}1353 \\
1381 \\
1410\end{array}$ & $\begin{array}{l}1356 \\
1384 \\
1412\end{array}$ & $\begin{array}{l}1359 \\
1387 \\
1415\end{array}$ & $\begin{array}{l}1362 \\
1390 \\
1418\end{array}$ & $\begin{array}{l}1365 \\
1393 \\
1421\end{array}$ & $\begin{array}{l}1367 \\
1395 \\
1424\end{array}$ & $\begin{array}{l}1370 \\
1398 \\
1426\end{array}$ & $\begin{array}{l}1373 \\
1401 \\
1429\end{array}$ & $\begin{array}{l}41.00 \\
42.00 \\
43.00\end{array}$ \\
\hline $\begin{array}{l}44.00 \\
45.00 \\
46.00\end{array}$ & $\begin{array}{l}1429 \\
1457 \\
1485\end{array}$ & $\begin{array}{l}1432 \\
1460 \\
1488\end{array}$ & $\begin{array}{l}1435 \\
1463 \\
1491\end{array}$ & $\begin{array}{l}1438 \\
1465 \\
1494\end{array}$ & $\begin{array}{l}1440 \\
1468 \\
1496\end{array}$ & $\begin{array}{l}1443 \\
1471 \\
1499\end{array}$ & $\begin{array}{l}1446 \\
1474 \\
1502\end{array}$ & $\begin{array}{l}1449 \\
1477 \\
1505\end{array}$ & $\begin{array}{l}1451 \\
1480 \\
1508\end{array}$ & $\begin{array}{l}1454 \\
1482 \\
1510\end{array}$ & $\begin{array}{l}1457 \\
1485 \\
1513\end{array}$ & $\begin{array}{l}44.00 \\
45.00 \\
46.00\end{array}$ \\
\hline $\begin{array}{l}47.00 \\
48.00 \\
49.00\end{array}$ & $\begin{array}{l}1513 \\
1541 \\
1570\end{array}$ & $\begin{array}{l}1516 \\
1544 \\
1573\end{array}$ & $\begin{array}{l}1519 \\
1547 \\
1576\end{array}$ & $\begin{array}{l}1522 \\
1550 \\
1578\end{array}$ & $\begin{array}{l}1524 \\
1553 \\
1581\end{array}$ & $\begin{array}{l}1527 \\
1556 \\
1584\end{array}$ & $\begin{array}{l}1530 \\
1558 \\
1587\end{array}$ & $\begin{array}{l}1533 \\
1561 \\
1590\end{array}$ & $\begin{array}{l}1536 \\
1564 \\
1593\end{array}$ & $\begin{array}{l}1539 \\
1567 \\
1596\end{array}$ & $\begin{array}{l}1541 \\
1570 \\
1599\end{array}$ & $\begin{array}{l}47.00 \\
48.00 \\
49.00\end{array}$ \\
\hline 50.00 & 1599 & 1602 & & & & & & & & & & 50.00 \\
\hline
\end{tabular}

* Based on the International Temperature Scale of 1948. 
Table 9. Iron-Constantan Thermocouples

(Emf in Absolute Millivolts. Temperatures in Degrees C(Int.1948) Reference Junctions at $0^{\circ} \mathrm{C}$ )

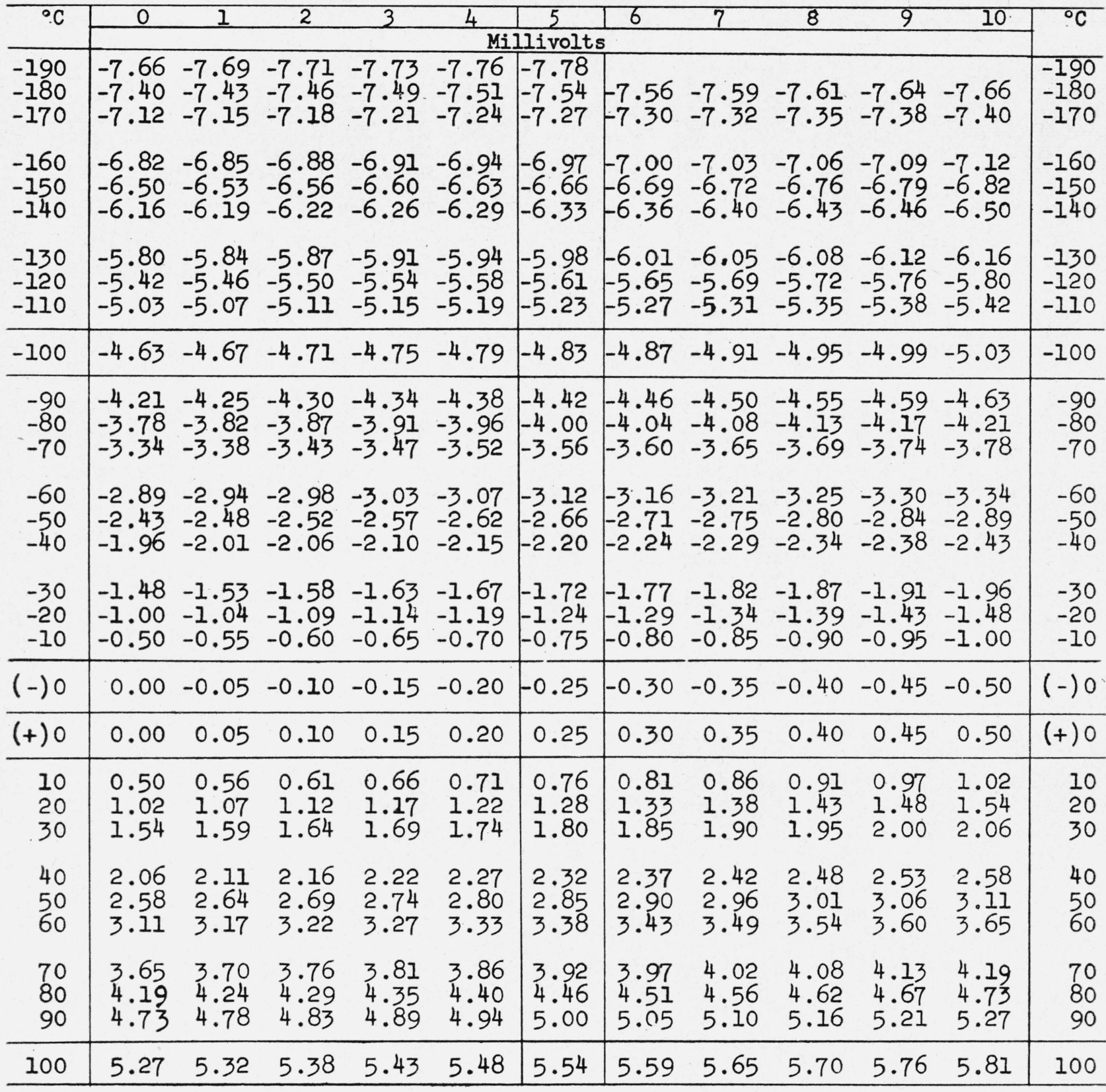


Table 9. Iron-Constantan Thermocouples-Continued

(Emf in Absolute Millivolts. Temperatures in Degrees C(Int.1948) Reference Junctions at $0^{\circ} \mathrm{C}$ )

\begin{tabular}{|c|c|c|c|c|c|c|c|c|c|c|c|c|}
\hline \multirow[t]{2}{*}{${ }^{\circ} \mathrm{C}$} & 0 & 1 & 2 & 3 & 4 & 5 & 6 & 7 & 8 & 9 & 10 & \multirow[t]{2}{*}{${ }^{\circ} \mathrm{C}$} \\
\hline & \multicolumn{11}{|c|}{ Millivolts } & \\
\hline 100 & 5.27 & 5.32 & 5.38 & 5.43 & 5.48 & 5.54 & 5.59 & 5.65 & 5.70 & 5.76 & 5.81 & 100 \\
\hline $\begin{array}{l}110 \\
120 \\
130\end{array}$ & $\begin{array}{l}5.81 \\
6.36 \\
6.90\end{array}$ & $\begin{array}{l}5.86 \\
6.41 \\
6.96\end{array}$ & $\begin{array}{l}5.92 \\
6.47 \\
7.01\end{array}$ & $\begin{array}{l}5.97 \\
6.52 \\
7.07\end{array}$ & $\begin{array}{l}6.03 \\
6.58 \\
7.12\end{array}$ & $\begin{array}{l}6.08 \\
6.63 \\
7.18\end{array}$ & $\begin{array}{l}6.14 \\
6.68 \\
7.23\end{array}$ & $\begin{array}{l}6.19 \\
6.74 \\
7.29\end{array}$ & $\begin{array}{l}6.25 \\
6.79 \\
7.34\end{array}$ & $\begin{array}{l}6.30 \\
6.85 \\
7.40\end{array}$ & $\begin{array}{l}6.36 \\
6.90 \\
7.45\end{array}$ & $\begin{array}{l}110 \\
120 \\
130\end{array}$ \\
\hline $\begin{array}{l}140 \\
150 \\
160\end{array}$ & $\begin{array}{l}7.45 \\
8.00 \\
8.56\end{array}$ & $\begin{array}{l}7.51 \\
8.06 \\
8.61\end{array}$ & $\begin{array}{l}7.56 \\
8.12 \\
8.67\end{array}$ & $\begin{array}{l}7.62 \\
8.17 \\
8.72\end{array}$ & $\begin{array}{l}7.67 \\
8.23 \\
8.78\end{array}$ & $\begin{array}{l}7.73 \\
8.28 \\
8.84\end{array}$ & $\begin{array}{l}7.78 \\
8.34 \\
8.89\end{array}$ & $\begin{array}{l}7.84 \\
8.39 \\
8.95\end{array}$ & $\begin{array}{l}7.89 \\
8.45 \\
9.00\end{array}$ & $\begin{array}{l}7.95 \\
8.50 \\
9.06\end{array}$ & $\begin{array}{l}8.00 \\
8.56 \\
9.11\end{array}$ & $\begin{array}{l}140 \\
150 \\
160\end{array}$ \\
\hline $\begin{array}{l}170 \\
180 \\
190\end{array}$ & $\begin{array}{r}9.11 \\
9.67 \\
10.22\end{array}$ & $\begin{array}{r}9.17 \\
9.72 \\
10.28\end{array}$ & $\begin{array}{r}9.22 \\
9.78 \\
10.34\end{array}$ & $\begin{array}{r}9.28 \\
9.83 \\
10.39\end{array}$ & $\begin{array}{r}9.33 \\
9.89 \\
10.45\end{array}$ & $\begin{array}{r}9.39 \\
9.95 \\
10.50\end{array}$ & $\begin{array}{r}9.44 \\
10.00 \\
10.56\end{array}$ & $\begin{array}{r}9.50 \\
10.06 \\
10.61\end{array}$ & $\begin{array}{r}9.56 \\
10.11 \\
10.67\end{array}$ & $\begin{array}{r}9.61 \\
10.17 \\
10.72\end{array}$ & 8 & $\begin{array}{l}170 \\
180 \\
190\end{array}$ \\
\hline 200 & 8 & 34 & 9 & 10 & 0 & 11.06 & 11.12 & 17 & 23 & 8 & & 200 \\
\hline $\begin{array}{l}210 \\
220 \\
230\end{array}$ & $\begin{array}{l}11.34 \\
11.89 \\
12.45\end{array}$ & $\begin{array}{l}11 . \\
12 .\end{array}$ & $\begin{array}{l}11.45 \\
12.00 \\
12.56\end{array}$ & $\begin{array}{l}11.50 \\
12.06 \\
12.62\end{array}$ & $\begin{array}{l}11.56 \\
12.12 \\
12.67\end{array}$ & $\begin{array}{l}11.62 \\
12.17 \\
12.73\end{array}$ & $\begin{array}{l}11.67 \\
12.23 \\
12.78\end{array}$ & $\begin{array}{l}11.73 \\
12.28 \\
12.84\end{array}$ & $\begin{array}{l}11.78 \\
12.34 \\
12.89\end{array}$ & $\begin{array}{l}11.84 \\
12.39 \\
12.95\end{array}$ & $\begin{array}{l}9 \\
5 \\
1\end{array}$ & $\begin{array}{l}210 \\
220 \\
230\end{array}$ \\
\hline $\begin{array}{l}240 \\
250 \\
260\end{array}$ & $\begin{array}{l}13.01 \\
13.56 \\
14.12\end{array}$ & $\begin{array}{l}13.62 \\
14.17\end{array}$ & $\begin{array}{l}13.12 \\
13.67 \\
14.23\end{array}$ & $\begin{array}{l}13.17 \\
13.73 \\
14.28\end{array}$ & $\begin{array}{l}13.23 \\
13.78 \\
14.34\end{array}$ & $\begin{array}{l}13.28 \\
13.84 \\
14.39\end{array}$ & $\begin{array}{l}13.34 \\
13.89 \\
14.45\end{array}$ & $\begin{array}{l}13.40 \\
13.95 \\
14.50\end{array}$ & $\begin{array}{l}13.45 \\
14.00 \\
14.56\end{array}$ & $\begin{array}{l}13.51 \\
14.06 \\
14.61\end{array}$ & $\begin{array}{l}6 \\
2 \\
7\end{array}$ & $\begin{array}{l}240 \\
250 \\
260\end{array}$ \\
\hline $\begin{array}{l}270 \\
280 \\
290\end{array}$ & $\begin{array}{l}14.67 \\
15.22 \\
15.77\end{array}$ & $\begin{array}{l}14.72 \\
15.28 \\
15.83\end{array}$ & $\begin{array}{l}14.78 \\
15.33 \\
15.88\end{array}$ & $\begin{array}{l}14.83 \\
15.39 \\
15.94\end{array}$ & $\begin{array}{l}14.89 \\
15.44 \\
16.00\end{array}$ & $\begin{array}{l}14.94 \\
15.50 \\
16.05\end{array}$ & $\begin{array}{l}15.00 \\
15 \cdot 55 \\
16.11\end{array}$ & $\begin{array}{l}15.06 \\
15.61 \\
16.16\end{array}$ & $\begin{array}{l}15.11 \\
15.66 \\
16.22\end{array}$ & $\begin{array}{l}15.17 \\
15.72 \\
16.27\end{array}$ & & $\begin{array}{l}270 \\
280 \\
290\end{array}$ \\
\hline 300 & - & 16.38 & 4 & 16 & 55 & 16 & 1 & 7 & 77 & 1 & & 300 \\
\hline $\begin{array}{l}310 \\
320 \\
330\end{array}$ & $\begin{array}{l}17 . \\
17 .\end{array}$ & $\begin{array}{l}17.48 \\
18.04\end{array}$ & $\begin{array}{l}16.99 \\
17.54 \\
18.09\end{array}$ & $\begin{array}{l}17.04 \\
17.60 \\
18.15\end{array}$ & $\begin{array}{l}17.10 \\
17.65 \\
18.20\end{array}$ & $\begin{array}{l}17.15 \\
17.71 \\
18.26\end{array}$ & $\begin{array}{l}17 \cdot 21 \\
17 \cdot 76 \\
18 \cdot 32\end{array}$ & $\begin{array}{l}17.26 \\
17.82 \\
18.37\end{array}$ & $\begin{array}{l}17.32 \\
17.87 \\
18.43\end{array}$ & $\begin{array}{l}17.37 \\
17.93 \\
18.48\end{array}$ & $\begin{array}{l}1 \\
1 \\
1\end{array}$ & $\begin{array}{l}310 \\
320 \\
330\end{array}$ \\
\hline $\begin{array}{l}340 \\
350 \\
360\end{array}$ & $\begin{array}{l}18.54 \\
19.09 \\
19.64\end{array}$ & $\begin{array}{l}18.59 \\
19.14 \\
19.70\end{array}$ & $\begin{array}{l}18.65 \\
19.20 \\
19.75\end{array}$ & $\begin{array}{l}18.70 \\
19.26 \\
19.81\end{array}$ & $\begin{array}{l}18.76 \\
19.31 \\
19.86\end{array}$ & $\begin{array}{l}18.81 \\
19.37 \\
19.92\end{array}$ & $\begin{array}{l}18.87 \\
19.42 \\
19.97\end{array}$ & $\begin{array}{l}18.92 \\
19.48 \\
20.03\end{array}$ & $\begin{array}{l}18.98 \\
19.53\end{array}$ & $\begin{array}{l}19.03 \\
19.59 \\
20.14\end{array}$ & $\begin{array}{l}9 \\
4 \\
0\end{array}$ & $\begin{array}{l}340 \\
350 \\
360\end{array}$ \\
\hline $\begin{array}{l}370 \\
380 \\
390 \\
\end{array}$ & $\begin{array}{l}20.20 \\
20.75 \\
21.30\end{array}$ & $\begin{array}{l}20.25 \\
20.80 \\
21.35\end{array}$ & $\begin{array}{l}20.31 \\
20.86 \\
21.41\end{array}$ & $\begin{array}{l}20.36 \\
20.91 \\
21.46\end{array}$ & $\begin{array}{l}20.42 \\
20.97\end{array}$ & $\begin{array}{l}20.47 \\
21.02 \\
21.57\end{array}$ & $\begin{array}{l}20.53 \\
21.08 \\
21.63\end{array}$ & $\begin{array}{l}20.58 \\
21.13 \\
21.68\end{array}$ & $\begin{array}{l}20.64 \\
21.19\end{array}$ & $\begin{array}{l}20.69 \\
21.24 \\
21.79\end{array}$ & 21 & $\begin{array}{l}370 \\
380 \\
390\end{array}$ \\
\hline 400 & 5 & 0 & 6 & 2 & 07 & 3 & ? & 4 & 22.29 & 35 & 0 & 40 \\
\hline
\end{tabular}


Table 9. Iron-Constanten Thermocouples-Continued

(Fmf in Absolute Millivolts. Temperatures in Degrees C(Int.1948) Reference Junctions at $0^{\circ} \mathrm{C}$ )

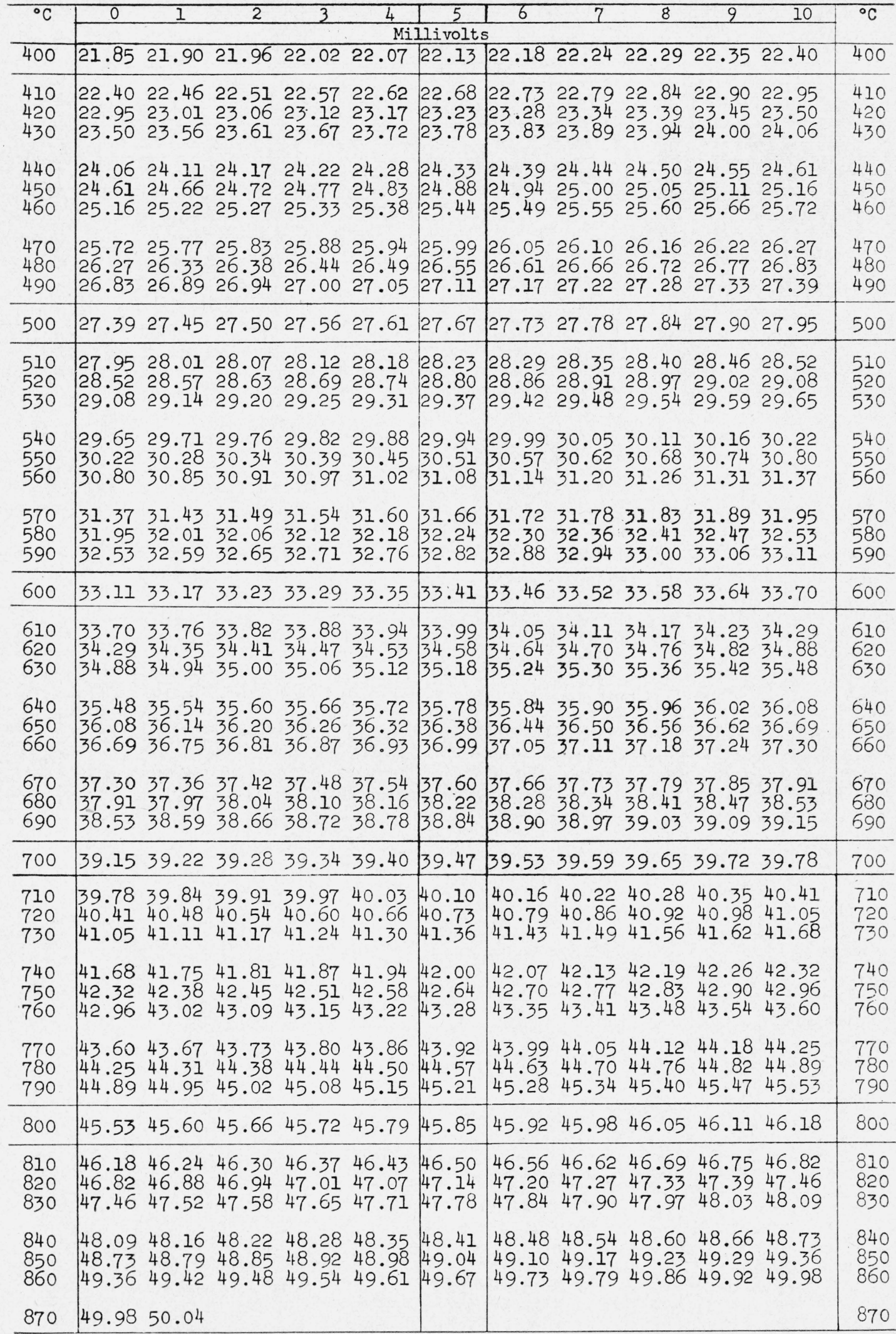


Table 10. Iron-Constantan Thermocouples

(Emf in Absolute Millivolts. Temperatures in Degrees C(Int.1948) Reference Junctions at $0^{\circ} \mathrm{C}$ )

\begin{tabular}{|c|c|c|c|c|c|c|c|c|c|c|c|c|}
\hline \multirow[t]{2}{*}{ Millivolts } & .00 & .10 & .20 & .30 & .40 & .50 & .60 & .70 & .80 & .90 & 1.00 & \multirow[t]{2}{*}{ Millivolts } \\
\hline & \multicolumn{11}{|c|}{ Degrees C } & \\
\hline-7.00 & -166 & -169 & -173 & -176 & -180 & -184 & -188 & -192 & -196 & & & -7.00 \\
\hline $\begin{array}{l}-6.00 \\
-5.00 \\
-4.00\end{array}$ & $\begin{array}{r}-136 \\
-109 \\
-85\end{array}$ & $\begin{array}{r}-138 \\
-112 \\
-87\end{array}$ & $\begin{array}{r}-141 \\
-114 \\
-90\end{array}$ & $\begin{array}{r}-144 \\
-117 \\
-92\end{array}$ & $\begin{array}{r}-147 \\
-119 \\
-94\end{array}$ & $\begin{array}{r}-150 \\
-122 \\
-97\end{array}$ & $\begin{array}{r}-153 \\
-125 \\
-99\end{array}$ & $\begin{array}{l}-156 \\
-127 \\
-102\end{array}$ & $\begin{array}{l}-159 \\
-130 \\
-104\end{array}$ & $\begin{array}{l}-163 \\
-133 \\
-107\end{array}$ & $\begin{array}{l}-166 \\
-136 \\
-109\end{array}$ & $\begin{array}{l}-6.00 \\
-5.00 \\
-4.00\end{array}$ \\
\hline $\begin{array}{l}-3.00 \\
-2.00 \\
-1.00\end{array}$ & $\begin{array}{l}-62 \\
-41 \\
-20\end{array}$ & $\begin{array}{l}-65 \\
-43 \\
-22\end{array}$ & $\begin{array}{l}-67 \\
-45 \\
-24\end{array}$ & $\begin{array}{l}-69 \\
-47 \\
-26\end{array}$ & $\begin{array}{l}-71 \\
-49 \\
-28\end{array}$ & $\begin{array}{l}-74 \\
-52 \\
-30\end{array}$ & $\begin{array}{l}-76 \\
-54 \\
-32\end{array}$ & $\begin{array}{l}-78 \\
-56 \\
-35\end{array}$ & $\begin{array}{l}-80 \\
-58 \\
-37\end{array}$ & $\begin{array}{l}-83 \\
-60 \\
-39\end{array}$ & $\begin{array}{l}-85 \\
-62 \\
-41\end{array}$ & $\begin{array}{l}-3.00 \\
-2.00 \\
-1.00\end{array}$ \\
\hline$(-) 0.00$ & 0 & -2 & -4 & -6 & -8 & -10 & -12 & -14 & -16 & -18 & -20 & $(-) 0.00$ \\
\hline$(+) 0.00$ & 0 & 2 & 4 & 6 & 8 & 10 & 12 & 14 & 16 & 18 & 20 & $(+) 0.00$ \\
\hline $\begin{array}{l}1.00 \\
2.00 \\
3.00\end{array}$ & $\begin{array}{l}20 \\
39 \\
58\end{array}$ & $\begin{array}{l}22 \\
41 \\
60\end{array}$ & $\begin{array}{l}24 \\
43 \\
62\end{array}$ & $\begin{array}{l}25 \\
45 \\
63\end{array}$ & $\begin{array}{l}27 \\
47 \\
65\end{array}$ & $\begin{array}{l}29 \\
48 \\
67\end{array}$ & $\begin{array}{l}31 \\
50 \\
69\end{array}$ & $\begin{array}{l}33 \\
52 \\
71\end{array}$ & $\begin{array}{l}35 \\
54 \\
73\end{array}$ & $\begin{array}{l}37 \\
56 \\
75\end{array}$ & $\begin{array}{l}39 \\
58 \\
77\end{array}$ & $\begin{array}{l}1.00 \\
2.00 \\
3.00\end{array}$ \\
\hline $\begin{array}{l}4.00 \\
5.00 \\
6.00\end{array}$ & $\begin{array}{r}77 \\
95 \\
113\end{array}$ & $\begin{array}{r}78 \\
97 \\
115\end{array}$ & $\begin{array}{r}80 \\
99 \\
117\end{array}$ & $\begin{array}{r}82 \\
101 \\
119\end{array}$ & $\begin{array}{r}84 \\
102 \\
121\end{array}$ & $\begin{array}{r}86 \\
104 \\
123\end{array}$ & $\begin{array}{r}88 \\
106 \\
124\end{array}$ & $\begin{array}{r}90 \\
108 \\
126\end{array}$ & $\begin{array}{r}91 \\
110 \\
128\end{array}$ & $\begin{array}{r}93 \\
112 \\
130\end{array}$ & $\begin{array}{r}95 \\
113 \\
132\end{array}$ & $\begin{array}{l}4.00 \\
5.00 \\
6.00\end{array}$ \\
\hline $\begin{array}{l}7.00 \\
8.00 \\
9.00\end{array}$ & $\begin{array}{l}132 \\
150 \\
168\end{array}$ & $\begin{array}{l}134 \\
152 \\
170\end{array}$ & $\begin{array}{l}135 \\
154 \\
172\end{array}$ & $\begin{array}{l}137 \\
155 \\
173\end{array}$ & $\begin{array}{l}139 \\
157 \\
175\end{array}$ & $\begin{array}{l}141 \\
159 \\
177\end{array}$ & $\begin{array}{l}143 \\
161 \\
179\end{array}$ & $\begin{array}{l}144 \\
163 \\
181\end{array}$ & $\begin{array}{l}146 \\
164 \\
182\end{array}$ & $\begin{array}{l}148 \\
166 \\
184\end{array}$ & $\begin{array}{l}150 \\
168 \\
186\end{array}$ & $\begin{array}{l}7.00 \\
8.00 \\
9.00\end{array}$ \\
\hline 10.00 & 186 & 188 & 190 & 191 & 193 & 195 & 197 & 199 & 200 & 202 & 204 & 10.00 \\
\hline $\begin{array}{l}11.00 \\
12.00 \\
13.00\end{array}$ & $\begin{array}{l}204 \\
222 \\
240\end{array}$ & $\begin{array}{l}206 \\
224 \\
242\end{array}$ & $\begin{array}{l}208 \\
226 \\
244\end{array}$ & $\begin{array}{l}209 \\
227 \\
245\end{array}$ & $\begin{array}{l}211 \\
229 \\
247\end{array}$ & $\begin{array}{l}213 \\
231 \\
249\end{array}$ & $\begin{array}{l}215 \\
233 \\
251\end{array}$ & $\begin{array}{l}217 \\
235 \\
253\end{array}$ & $\begin{array}{l}218 \\
236 \\
254\end{array}$ & $\begin{array}{l}220 \\
238 \\
256\end{array}$ & $\begin{array}{l}222 \\
240 \\
258\end{array}$ & $\begin{array}{l}11.00 \\
12.00 \\
13.00\end{array}$ \\
\hline $\begin{array}{l}14.00 \\
15.00 \\
16.00\end{array}$ & $\begin{array}{l}258 \\
276 \\
294\end{array}$ & $\begin{array}{l}260 \\
278 \\
296\end{array}$ & $\begin{array}{l}262 \\
280 \\
298\end{array}$ & $\begin{array}{l}263 \\
281 \\
300\end{array}$ & $\begin{array}{l}265 \\
283 \\
301\end{array}$ & $\begin{array}{l}267 \\
285 \\
303\end{array}$ & $\begin{array}{l}269 \\
287 \\
305\end{array}$ & $\begin{array}{l}271 \\
289 \\
307\end{array}$ & $\begin{array}{l}272 \\
290 \\
309\end{array}$ & $\begin{array}{l}274 \\
292 \\
310\end{array}$ & $\begin{array}{l}276 \\
294 \\
312\end{array}$ & $\begin{array}{l}14.00 \\
15.00 \\
16.00\end{array}$ \\
\hline $\begin{array}{l}17.00 \\
18.00 \\
19.00\end{array}$ & $\begin{array}{l}312 \\
330 \\
348\end{array}$ & $\begin{array}{l}314 \\
332 \\
350\end{array}$ & $\begin{array}{l}316 \\
334 \\
352\end{array}$ & $\begin{array}{l}318 \\
336 \\
354\end{array}$ & $\begin{array}{l}319 \\
338 \\
356\end{array}$ & $\begin{array}{l}321 \\
339 \\
357\end{array}$ & $\begin{array}{l}323 \\
341 \\
359\end{array}$ & $\begin{array}{l}325 \\
343 \\
361\end{array}$ & $\begin{array}{l}327 \\
345 \\
363\end{array}$ & $\begin{array}{l}329 \\
347 \\
365\end{array}$ & $\begin{array}{l}330 \\
348 \\
366\end{array}$ & $\begin{array}{l}17.00 \\
18.00 \\
19.00\end{array}$ \\
\hline 20.00 & 366 & 368 & 370 & 372 & 374 & 376 & 377 & 379 & 381 & 383 & 385 & 20.00 \\
\hline
\end{tabular}


Table 10. Iron-Constantan Thermocouples-Continued

(Emf in Absolute Millivolts. Temperatures in Degrees C(Int.1948) Reference Junctions at $0^{\circ} \mathrm{C}$ )

\begin{tabular}{|c|c|c|c|c|c|c|c|c|c|c|c|c|}
\hline \multirow[t]{2}{*}{ Millivolts } & .00 & .10 & .20 & .30 & .40 & .50 & .60 & .70 & .80 & .90 & 1.00 & \multirow[t]{2}{*}{ Millivolts } \\
\hline & \multicolumn{11}{|c|}{ Degrees C } & \\
\hline 20.00 & 366 & 368 & 370 & 372 & 374 & 376 & 377 & 379 & 381 & 383 & 385 & 20.00 \\
\hline $\begin{array}{l}21.00 \\
22.00 \\
23.00\end{array}$ & $\begin{array}{l}385 \\
403 \\
421\end{array}$ & $\begin{array}{l}386 \\
405 \\
423\end{array}$ & $\begin{array}{l}388 \\
406 \\
424\end{array}$ & $\begin{array}{l}390 \\
408 \\
426\end{array}$ & $\begin{array}{l}392 \\
410 \\
428\end{array}$ & $\begin{array}{l}394 \\
412 \\
430\end{array}$ & $\begin{array}{l}395 \\
414 \\
432\end{array}$ & $\begin{array}{l}397 \\
416 \\
434\end{array}$ & $\begin{array}{l}399 \\
417 \\
435\end{array}$ & $\begin{array}{l}401 \\
419 \\
437\end{array}$ & $\begin{array}{l}403 \\
421 \\
439\end{array}$ & $\begin{array}{l}21.00 \\
22.00 \\
23.00\end{array}$ \\
\hline $\begin{array}{l}24.00 \\
25.00 \\
26.00\end{array}$ & $\begin{array}{l}439 \\
457 \\
475\end{array}$ & $\begin{array}{l}441 \\
459 \\
477\end{array}$ & $\begin{array}{l}443 \\
461 \\
479\end{array}$ & $\begin{array}{l}444 \\
463 \\
481\end{array}$ & $\begin{array}{l}446 \\
464 \\
482\end{array}$ & $\begin{array}{l}448 \\
466 \\
484\end{array}$ & $\begin{array}{l}450 \\
468 \\
486\end{array}$ & $\begin{array}{l}452 \\
470 \\
488\end{array}$ & $\begin{array}{l}453 \\
472 \\
489\end{array}$ & $\begin{array}{l}455 \\
473 \\
491\end{array}$ & $\begin{array}{l}457 \\
475 \\
493\end{array}$ & $\begin{array}{l}24.00 \\
25.00 \\
26.00\end{array}$ \\
\hline $\begin{array}{l}27.00 \\
28.00 \\
29.00\end{array}$ & $\begin{array}{l}493 \\
511 \\
529\end{array}$ & $\begin{array}{l}495 \\
513 \\
530\end{array}$ & $\begin{array}{l}497 \\
514 \\
532\end{array}$ & $\begin{array}{l}499 \\
516 \\
534\end{array}$ & $\begin{array}{l}500 \\
518 \\
536\end{array}$ & $\begin{array}{l}502 \\
520 \\
537\end{array}$ & $\begin{array}{l}504 \\
522 \\
539\end{array}$ & $\begin{array}{l}506 \\
523 \\
541\end{array}$ & $\begin{array}{l}507 \\
525 \\
543\end{array}$ & $\begin{array}{l}509 \\
527 \\
544\end{array}$ & $\begin{array}{l}511 \\
529 \\
546\end{array}$ & $\begin{array}{l}27.00 \\
28.00 \\
29.00\end{array}$ \\
\hline 30.00 & 546 & 548 & 550 & 551 & 553 & 555 & 557 & 558 & 560 & 562 & 564 & 30.00 \\
\hline $\begin{array}{l}31.00 \\
32.00 \\
33.00\end{array}$ & $\begin{array}{l}564 \\
581 \\
598\end{array}$ & $\begin{array}{l}565 \\
583 \\
600\end{array}$ & $\begin{array}{l}567 \\
584 \\
601\end{array}$ & $\begin{array}{l}569 \\
586 \\
603\end{array}$ & $\begin{array}{l}571 \\
588 \\
605\end{array}$ & $\begin{array}{l}572 \\
589 \\
607\end{array}$ & $\begin{array}{l}574 \\
591 \\
608\end{array}$ & $\begin{array}{l}576 \\
593 \\
610\end{array}$ & $\begin{array}{l}577 \\
595 \\
612\end{array}$ & $\begin{array}{l}579 \\
596 \\
613\end{array}$ & $\begin{array}{l}581 \\
598 \\
615\end{array}$ & $\begin{array}{l}31.00 \\
32.00 \\
33.00\end{array}$ \\
\hline $\begin{array}{l}34.00 \\
35.00 \\
36.00\end{array}$ & $\begin{array}{l}615 \\
632 \\
649\end{array}$ & $\begin{array}{l}617 \\
634 \\
650\end{array}$ & $\begin{array}{l}618 \\
635 \\
652\end{array}$ & $\begin{array}{l}620 \\
637 \\
654\end{array}$ & $\begin{array}{l}622 \\
639 \\
655\end{array}$ & $\begin{array}{l}624 \\
640 \\
657\end{array}$ & $\begin{array}{l}625 \\
642 \\
659\end{array}$ & $\begin{array}{l}627 \\
644 \\
660\end{array}$ & $\begin{array}{l}629 \\
645 \\
662\end{array}$ & $\begin{array}{l}630 \\
647 \\
664\end{array}$ & $\begin{array}{l}632 \\
649 \\
665\end{array}$ & $\begin{array}{l}34.00 \\
35.00 \\
36.00\end{array}$ \\
\hline $\begin{array}{l}37.00 \\
38.00 \\
39.00\end{array}$ & $\begin{array}{l}665 \\
681 \\
698\end{array}$ & $\begin{array}{l}667 \\
683 \\
699\end{array}$ & $\begin{array}{l}668 \\
685 \\
701\end{array}$ & $\begin{array}{l}670 \\
686 \\
702\end{array}$ & $\begin{array}{l}672 \\
688 \\
704\end{array}$ & $\begin{array}{l}673 \\
690 \\
706\end{array}$ & $\begin{array}{l}675 \\
691 \\
707\end{array}$ & $\begin{array}{l}677 \\
693 \\
709\end{array}$ & $\begin{array}{l}678 \\
694 \\
710\end{array}$ & $\begin{array}{l}680 \\
696 \\
712\end{array}$ & $\begin{array}{l}681 \\
698 \\
713\end{array}$ & $\begin{array}{l}37.00 \\
38.00 \\
39.00\end{array}$ \\
\hline 40.00 & 713 & 715 & 717 & 718 & 720 & 721 & 723 & 725 & 726 & 728 & 729 & 40.00 \\
\hline $\begin{array}{l}41.00 \\
42.00 \\
43.00\end{array}$ & $\begin{array}{l}729 \\
745 \\
761\end{array}$ & $\begin{array}{l}731 \\
747 \\
762\end{array}$ & $\begin{array}{l}732 \\
748 \\
764\end{array}$ & $\begin{array}{l}734 \\
750 \\
765\end{array}$ & $\begin{array}{l}736 \\
751 \\
767\end{array}$ & $\begin{array}{l}737 \\
753 \\
768\end{array}$ & $\begin{array}{l}739 \\
754 \\
770\end{array}$ & $\begin{array}{l}740 \\
756 \\
772\end{array}$ & $\begin{array}{l}742 \\
757 \\
773\end{array}$ & $\begin{array}{l}743 \\
759 \\
775\end{array}$ & $\begin{array}{l}745 \\
761 \\
776\end{array}$ & $\begin{array}{l}41.00 \\
42.00 \\
43.00\end{array}$ \\
\hline $\begin{array}{l}44.00 \\
45.00 \\
46.00\end{array}$ & $\begin{array}{l}776 \\
792 \\
807\end{array}$ & $\begin{array}{l}778 \\
793 \\
809\end{array}$ & $\begin{array}{l}779 \\
795 \\
810\end{array}$ & $\begin{array}{l}781 \\
796 \\
812\end{array}$ & $\begin{array}{l}782 \\
798 \\
814\end{array}$ & $\begin{array}{l}784 \\
799 \\
815\end{array}$ & $\begin{array}{l}785 \\
801 \\
817\end{array}$ & $\begin{array}{l}787 \\
803 \\
818\end{array}$ & $\begin{array}{l}789 \\
804 \\
820\end{array}$ & $\begin{array}{l}790 \\
806 \\
821\end{array}$ & $\begin{array}{l}792 \\
807 \\
823\end{array}$ & $\begin{array}{l}44.00 \\
45.00 \\
46.00\end{array}$ \\
\hline $\begin{array}{l}47.00 \\
48.00 \\
49.00\end{array}$ & $\begin{array}{l}823 \\
839 \\
854\end{array}$ & $\begin{array}{l}824 \\
840 \\
856\end{array}$ & $\begin{array}{l}826 \\
842 \\
858\end{array}$ & $\begin{array}{l}828 \\
843 \\
859\end{array}$ & $\begin{array}{l}829 \\
845 \\
861\end{array}$ & $\begin{array}{l}831 \\
846 \\
862\end{array}$ & $\begin{array}{l}832 \\
848 \\
864\end{array}$ & $\begin{array}{l}834 \\
850 \\
866\end{array}$ & $\begin{array}{l}835 \\
851 \\
867\end{array}$ & $\begin{array}{l}837 \\
853 \\
869\end{array}$ & $\begin{array}{l}839 \\
854 \\
870\end{array}$ & $\begin{array}{l}47.00 \\
48.00 \\
49.00\end{array}$ \\
\hline 50.00 & 870 & 872 & & & & & & & & & & 50.00 \\
\hline
\end{tabular}

Washington, March 11, 1953. 